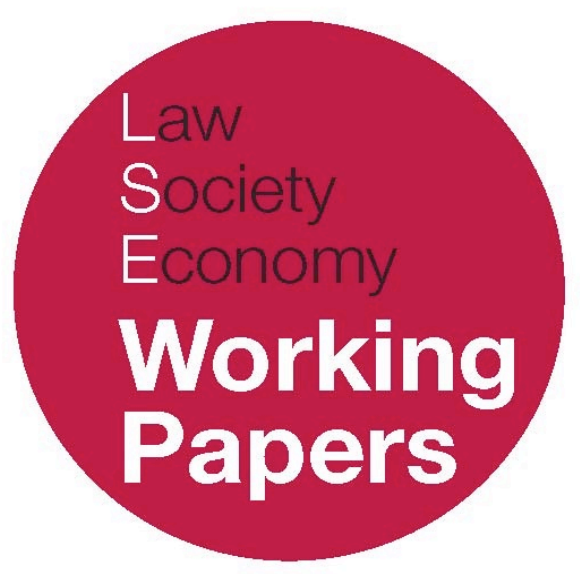

\title{
Women, Crime and Character in Twentieth Century Law and Literature: In Search of the Modern Moll Flanders
}

\author{
Nicola Lacey \\ LSE Law, Society and Economy Working Papers 20/2017 \\ London School of Economics and Political Science \\ Law Department
}

\footnotetext{
This paper can be downloaded without charge from LSE Law, Society and Economy Working Papers at: www.lse.ac.uk/collections/law/wps/wps.htm and the Social Sciences Research Network electronic library at: http://ssrn.com/abstract=3083981

(C) Nicola Lacey. Users may download and/or print one copy to facilitate their private study or for noncommercial research. Users may not engage in further distribution of this material or use it for any profitmaking activities or any other form of commercial gain.
} 


\title{
Women, Crime and Character in Twentieth Century Law and Literature: In Search of the Modern Moll Flanders
}

\author{
Nicola Lacey ${ }^{*}$
}

\begin{abstract}
The Twentieth Century saw decisive changes in women's legal, social, economic and political position. But how far have these changes been reflected in women's position as subjects of criminalisation in the courts, in legal thought or in literary fiction? This paper takes up the story of the gradual marginalisation of criminal women in both legal and literary history, asking whether a criminal heroine such as Moll Flanders (1722) is thinkable again, and what this can tell us about conceptions of women as subjects of criminal law. How far do the conceptions of, and dilemmas about, female subjectivity, agency, capacity and character which emerge successively in 20th Century literary culture reflect and illuminate the relevant patterns and debates in criminal law and philosophy?
\end{abstract}

\footnotetext{
* School Professor of Law, Gender and Social Policy; I am deeply grateful to Zelia Gallo, Arlie Loughnan, Anne Phillips, Ngaire Naffine and David Soskice, each of whom gave me comments on a draft of this lecture; to my colleagues in the Law Department at LSE - in particular Neil Duxbury, Nick Sage and Andy Summers - for their feedback on a draft presented to our department research seminar; and to David Hope for exemplary research assistance.
} 


\section{INTRODUCTION}

In this paper, I investigate the fate of women in the $20^{\text {th }}$ Century English criminal justice system, taking as my departure point this striking early twentieth century image of a woman looking out of Holloway Prison. ${ }^{1}$

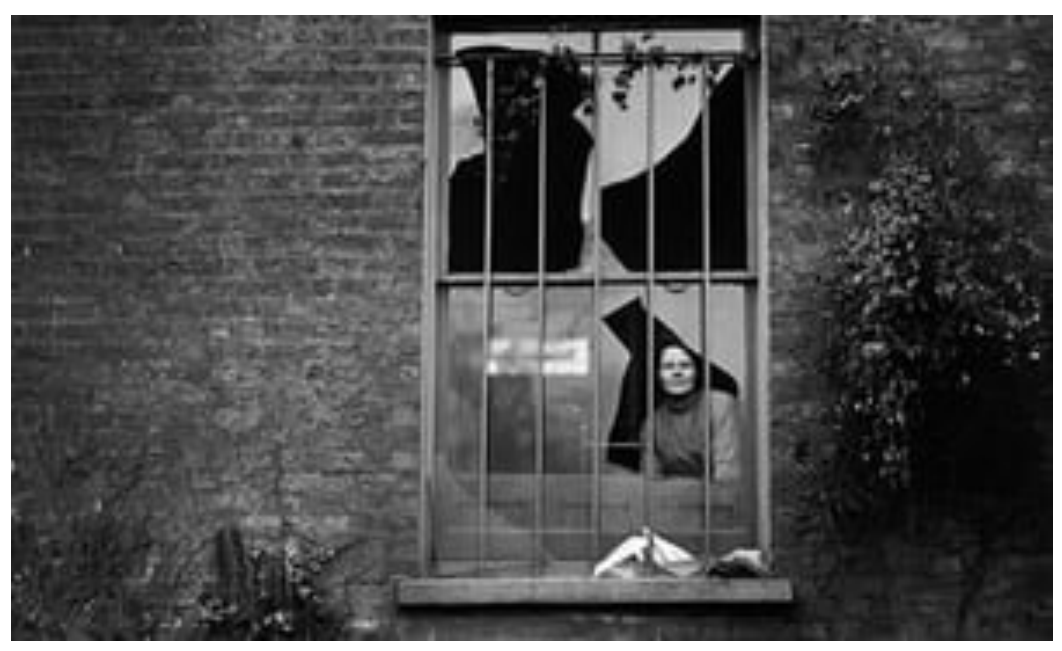

Drawing on both literary and legal sources, I venture an explanation for their continuing low numbers among offenders, notwithstanding the huge social changes in women's legal, political and economic position during the course of the last hundred years. At the end of the $19^{\text {th }}$ Century, notwithstanding the existence of a range of criminal classification statutes, some of which were specifically targeted at women, women made up a mere $18 \%$ of those convicted of the more serious offences, and a mere $17 \%$ of those in prison. At the time of this photograph, the women's prison population - particularly that at Holloway - was moreover swollen by the incarceration, not to mention force feeding, of many arrested during suffragette protests. We don't know if this woman was herself a suffragette, but the caption tells us that the window through which she looks out has been shattered in a suffragette protest outside the prison. On the face of it, we might expect the image to stand as a symbol of forms of agentic female law-breaking as women slowly come to assume rights, occupy roles and gain opportunities, exclusion from which had helped keep them among a small minority of law-breakers for the previous 150 years. Instead, Holloway Prison stands as a metaphor for what turned out to be a very different $20^{\text {th }}$ Century story: one in which the marginal place of women among

\footnotetext{
$1<$ https:/ $/$ www.google.co.uk $/$ search?q=holloway + prison + women + guardian\&client $=$ safari\&channel=m ac_bm\&dcr $=0 \&$ source $=\operatorname{lnms\& tbm}=$ isch\&sa $=$ X\&ved $=0$ ahUKEwip $46 \mathrm{HJmar} X A h X F I 8 A K H S q x B R s$ Q_AUICygC\&biw=1264\&bih=783\#imgrc=2a9_CBirwBN_HM> accessed 6 November 62017.
} 
those criminalised increased rather than declined. An emblem of Victorian discipline re-imagined (though never entirely realised) as mental hospital, Holloway exemplifies the continued tendency to pathologise female criminality. Ultimately closed down and destined to become profitable residential housing, we might regard its demise as a product of the forces of capitalism in the form of London's inflated property market. But of greater significance for this paper is the fact that the repeated reports documenting the prison's failings betoken more fundamentally not only the lack of any coherent policy on women offenders through much of the Century, but also a deep perplexity about the very notion of female deviance. ${ }^{2}$

Amid the huge variety of forms of crime and criminalisation across time and space - a variety which makes it virtually impossible to make generalisations about crime, and arguably poses persistent methodological challenges to the very idea of criminology as a discipline - the gendered nature of criminalisation is remarkably pervasive across systems. Women, in most developed countries over the last 200 years, make up a small minority of those formally identified as offenders. This in itself makes the gendering of social processes of criminalisation a central question for the social sciences (a fact which had however escaped social scientists until they were alerted by the pioneering work of feminist scholars like Carol Smart, ${ }^{3}$ Frances Heidensohn ${ }^{4}$ and Ngaire Naffine ${ }^{5}$.) But painstaking research - notably by American scholars Malcolm Feeley and Deborah Little, ${ }^{6}$ as well as subsequent comparative work by Feely and Hadar Aviram, ${ }^{7}$ has shown that there are fascinating historical exceptions to this usual gender ratio, a key one being London in the late $17^{\text {th }}$ and early $18^{\text {th }}$ Centuries, when women achieved parity with men among those convicted

2 See for example the Prison Inspectorate's Report of 2013

http://www.justiceinspectorates.gov.uk/prisons/wp-content/uploads/sites/4/2014/03/holloway2013.pdf

Despite some improvements in subsequent years -

https://www.justiceinspectorates.gov.uk/hmiprisons/wp-

content/uploads/sites/4/2016/02/Holloway-web-2015.pdf - Holloway was scheduled for closure in 2016. For a telling picture of the pathologies of women's imprisonment in the Twentieth Century, and of the power of gender norms in shaping the discipline of women in prison, see Pat Carlen, Women's Imprisonment (Routledge 1983).

${ }_{3}^{3}$ Carol Smart, Women, Crime and Criminology (London: Routledge 1976); Law, Crime and Sexuality (London: Sage 1995).

${ }^{4}$ Frances Heidensohn, Women and Crime (London: Macmillan 1985).

${ }^{5}$ Ngaire Naffine, Female Crime: The Construction of Women in Criminology (Sydney: Allen and Unwin 1987).

6 'The Vanishing Female: The decline of women in the criminal process 1687-1912' Law and Society Review (1981) 719.

7 'Social Historical Studies of Women, Crime and Courts', Annual Review of Law and Social Science 6: 151171 (2010); Malcolm Feeley, 'The decline of women in the criminal process: a comparative history' Criminal Justice History 15: 235-74 (1994). Feeley and Aviram's data show women to have been a significantly greater proportion of offenders in several European countries during the $17^{\text {th }}$ and early $18^{\text {th }}$ Centuries, with the proportion dropping from the mid $18^{\text {th }}$ Century through the $19^{\text {th }}$ Century. They suggest that the decline of women in the criminal process was a product of a move from public to private patriarchy, as the development of industrial capitalism, and associated changes in family structure, consolidated by protective legislation, deprived women of forms of economic opportunity and social status available to them in the era of family capitalism, in which their labour was often crucial to household finances. 
at the Old Bailey, London's main criminal court: a further reminder that these striking differences are socially produced. ${ }^{8}$

In a series of lectures delivered a decade ago, I argued that we could draw on cultural resources, notably realist novels, to shed light on the reasons for these variations in gender patterns of criminalisation. My starting point was Daniel Defoe's vivid (and persistent!) female offender, Moll Flanders (1722). In the early $18^{\text {th }}$ Century, it seemed, Defoe found it natural to write a novel whose heroine was a sexually adventurous, socially marginal property offender. But my reading showed that, only half a century later, this would have been next to unthinkable. In the book which eventually emerged from my attempts to think through why and how this had happened, and what it meant for criminal law, the disappearance of Moll Flanders, and her supersession in the annals of literary female offenders in the realist tradition by heroines like Tess of the d'Urbervilles (1891) served as a metaphor for fundamental changes in ideas of selfhood, gender and social order in $18^{\text {th }}$ and $19^{\text {th }}$ Century England. Drawing on law, literature, philosophy and social and economic history, I argued that these broad changes underpinned a radical shift in mechanisms of responsibility-attribution, with decisive implications for the criminalisation of women. To sum up the substantive argument, I suggested that it may have been easier to insert women into the (of course highly gendered) conceptions of criminal character which drove early $18^{\text {th }}$ Century attribution practices than to accommodate them within a conception of responsibility as founded in choice and capacity - a framework which was moreover emerging just as the acceptance of women's capacity and entitlement to exercise their agency was becoming more constrained, and women were increasingly subject to coercive informal discipline, as their bodies came to bear the burden of representing bourgeois respectability.

In the book which emerged from those lectures, ${ }^{9} \mathrm{I}$ focused in particular on the question of how the treatment and understanding of female criminality was changing during the era which saw the construction of the main building blocks of the modern criminal process, and how these understandings related in turn to broader ideas about sexual difference, social order and individual agency. In the slow movement from a world in which criminal judgment is motivated by type- or statusbased assessments of culpability, to a world in which individual psychological states become an object of proof in criminal trials - a move which is not complete until the mid-20th Century, and which encompasses even today only part of the terrain of criminal law - Moll Flanders stands as a fascinating landmark. The question which she poses - what counts as good character in an emerging capitalist world in which

\footnotetext{
8 See also Greg T. Smith, 'Long Term Trends in Female and Male Involvement in Crime (p. 139-157) and Barry Godfrey, 'A Historical Perspective on Criminal Justice Responses to Female and Male Offending' (p. 158-174) in Rosemary Gartner and Bill McCarthy (eds.) The Oxford Handbook of Gender, Sex and Crime (Oxford University Press 2014).

${ }^{9}$ Women, Crime and Character: From Moll Flanders to Tess of the D'Urbervilles (Oxford University Press 2008); the thesis of my book is consistent with Feeley's and Aviram's interpretation (op cit) while concentrating on a somewhat different evidential base.
} 
similar characteristics underpin success in crime and in commerce - echoes down the centuries, and has yet to be satisfactorily answered. In the long search for an answer, Moll's female descendants were caught up for over two centuries in a cluster of not only structural changes but also normative developments of manners, morals and, finally, medicine - which contributed to the unthinkability of Moll by the era of Tess.

At the conclusion of the lectures, I put a question to my audience: that of whether, in 2008, Moll Flanders was thinkable again - and, if so, whether this was a good thing or a bad. But of course, this was disingenuous: the question was really to myself, and I have been puzzling about it ever since. Answering it - or even beginning to answer it - however, required me first to complete my historical analysis of the trajectory of ideas and attribution practices of criminal responsibility through the $20^{\text {th }}$ century - a project which was concluded last year with the publication of In Search of Criminal Responsibility: Ideas, Interests and Institutions. ${ }^{10}$ At that point, an invitation to deliver a lecture at the British Academy ${ }^{11}$ provided a good opportunity to bring the social sciences and humanities into dialogue with one another. So, this paper is a preliminary attempt to bring my story of women, crime and character up to the millennium.

The paper will proceed as follows. First, I briefly draw on some statistics to illustrate the overall trends in female criminalisation and incarceration during the $20^{\text {th }}$ Century, drawing out some implications for how women have been inserted into the prevailing conceptions of responsibility via the practices of criminalisation which they enable. Second, I sketch and compare the conceptions of selfhood and responsible agency to be found in criminology, the criminal law, the criminal process and $20^{\text {th }}$ Century literary fiction. Here I note various methodological complexities as compared with a literary analysis of the earlier period, while arguing that law and literature have continued to share a sufficient range of preoccupations as to maintain the validity of this methodology, albeit with some adaptation. Third, I focus specifically on legal and literary representations of women, exploring what light representations of women's counter-normative - ie. bad! - behavior in literary fiction can shed on the patterns of female criminalization. And finally, I pose some questions about the implications of this tentative interpretation for methodology in the social sciences.

\footnotetext{
10 Oxford University Press 2016

${ }^{11}$ Maccabaean Lecture 2017 https://www.britac.ac.uk/maccabaean-lectures-jurisprudence
} 


\section{GENDER, CRIME AND PUNISHMENT THROUGH THE 20TH CENTURY}

Let us begin, then, by considering the ways in which criminal law 'sees', 'thinks about', constructs and responds to women, as represented by the bare statistics.

To assess the gender dynamics of criminal responsibility in the $20^{\text {th }}$ Century, it is useful to start with some fairly basic data, of the kind from which Feeley and Little launched their $1^{\text {th }}$-19 th Century analysis in 1981. I should preface this discussion by acknowledging that official crime statistics must carry a large health warning. First, with the exception of rare offences such as homicide, changes in the definition and range of offences, and in the way in which they are grouped in the official records, make it tricky to construct robust series over a significant period of time. Second, the official statistics represent - though they make it all too easy to forget this - the culmination of a complex set of processes of social labelling and the exercise of power, as opposed to 'raw facts'. Third, the techniques developed in the late twentieth century to counter these difficulties - notably crime surveys, which give us some purchase on the extent to which the official records distort the underlying behaviour which they purport to represent - are not available for the whole period. As a result of these difficulties, some forms of criminology have tended to avoid the official statistics altogether. Moreover some feminist criminologists have been further prompted in this direction by the sense that the official statistics risk strengthening the reified, biological understandings of criminality which are so pervasive in early criminology, and which persisted for a yet longer period in relation to women. ${ }^{12}$ Though each contains articles which draw on official statistics, neither the latest edition of the Oxford Handbook of Criminology ${ }^{13}$ nor the Oxford Handbook of Gender, Sex and Crime ${ }^{14}$ includes a single table or figure presenting officially recorded crime. My view, however, is that statistics-avoidance in criminology has been overdone, and that the statistics over a century do tell us something important. While they gloss over the forms of offending and labelling behaviour and the motivations underlying the figures, they nonetheless represent real exercise of state power, and track its focus and extent over time. My approach here has therefore been to enlist the assistance of a very skilled econometrician - David Hope, to whose meticulous work I owe a huge debt - to construct the most robust set of data possible, at ten year intervals through the century.

Here, first, are the imprisonment figures, showing both women as a proportion of the prison population and women prisoners as a proportion of the female

\footnotetext{
12 Carol Smart, Women, Crime and Criminology (op cit; Frances Heidensohn, Women and Crime (op cit); Ngaire Naffine, Female Crime: The Construction of Women in Criminology (op cit); Ngaire Naffine, Feminism and Criminology (Oxford: Polity Press 1996); Hilary Allen, Justice Unbalanced: Gender, Psychiatry and Judicial Decisions (Milton Keynes: Open University Press 1987).

$136^{\text {th }}$ edition, ed. Alison Liebling, Shadd Maruna and Lesley McCara (Oxford University Press 2017).

14 Op cit.
} 
population as a whole. Unlike the crime statistics, these figures are easy to collect, and they are very interesting, for at least two reasons. First, the number of women in prison in the first decade of the Century will certainly have been swollen by the punitive state reaction to the suffragettes' protests, which led to around a thousand women being imprisoned between the turn of the Century and the First World Wara significant number given the overall size of the women's prison population at the time. ${ }^{15}$ Another factor is that the figures will have been affected by changes in how the statistics are constructed, or by the impact of the criminal classification statutes of the period, which targeted particular groups of women. ${ }^{16}$ Whatever the detailed reasons, women turn out to have been quite a substantial minority of the prison population not long after the appearance of victimised, relatively powerless Tess of the d'Urbervilles. If the criminal classification statutes are indeed an important part of the explanation, this would back up my argument in $W^{2}$ omen Crime and Character ${ }^{17}$ that gender-specific ideas of criminal character as a basis for responsibilityattribution might facilitate the criminalisation of women, while strictly capacity or opportunity-based practices of responsibility - attribution might be less likely to lead to the criminalisation of women, in circumstances in which women's opportunities were restricted and their agentic capacities called into doubt.

\section{Women as a proportion of the prison population in the Twentieth Century ${ }^{18}$ : Figures 1.1 and 1.2 of the Appendix.}

As you see from these Figures, while absolute numbers of women in prison have risen over the course of the $20^{\text {th }}$ Century, the female proportion of the overall prison population has in fact fallen from $17 \%$ to around $5 \%$, while the drop in the proportion of the overall female population incarcerated has fallen even further. Overall, what is most striking is the fact that, even if we take as our starting point 1930 - just two years after the franchise was extended to all women, marking the moment of women's full formal entry into citizenship - the figures are remarkably stable, and remarkably low, right through to the end of the Century, albeit with a spike during the Second World War and a significant rise in the Century's final decade. Now let us turn to the crime statistics, for which we have constructed three decadely measures through the century: women as a proportion of those convicted

15 June Purvis (1995). "The Prison Experiences of the Suffragettes in Edwardian Britain". Women's History Review. 4 (1): 103-133. doi: $10.1080 / 09612029500200073$ p. 103. The number of women in prison ranged from a peak of about 3,500 to 2,000 at the start of the First World War.

16 Lucia Zedner, Women, Crime and Custody in Victorian England (Oxford University Press 1991).

17 Op. cit.

18 Allen, G., \& Dempsey, N. (2016). Prison Population Statistics. House of Commons Library Briefing Paper, No. SN/SG/04334, 4 July 2016. Unsurprisingly, and as can be seen from the figure for 1940, the proportion of women rose during each of the two world wars, reaching 18.4\% in 1916. The persisting gender differences in imprisonment also characterise a wide range of jurisdictions on World Prison Brief data for last year. Among democratic advanced economies, the proportion of women in the prison system ranges from $3.4 \%$ in France up to $9.3 \%$ in the USA, via $4.5 \%$ in England and Wales, $5.1 \%$ in Scotland, 5.6\% in Sweden, and 8.0\% in Australia (World Prison Brief data, http://www.prisonstudies.org/world-prison-brief-data (accessed 18 March 2017). 
of violence against the person; as a proportion of those convicted of a group of common property offences; and as a proportion of those convicted of all indictable offences.

\section{Figures 2.1 - 2.3 (See Appendix)}

Notwithstanding a steady increase in the female proportion of those convicted of violence against the person from the 1960s on, and a less marked but definite concomitant rise in the property offences, in the case of violence, women at the millennium do not reach the proportionate representation of the beginning of the Century, while in property offences, they do no more than match it.

Again, we must remember that these figures smooth out huge differences between different forms of offending - and in particular give no sense of the impact and scale of forms of criminalisation trained with particular intensity on the social control of women - notably offences relating to prostitution, infanticide and abortion. ${ }^{19}$ The prison figures also exclude other forms of semi-carceral social control such as approved schools and commitment to mental hospitals. ${ }^{20}$ Yet, notwithstanding some increase in the late $20^{\text {th }}$ Century, compare the relative stability of these figures with the dramatic changes in women's legal, social and economic status and opportunities during this period (as crudely represented here by figures on labour market participation and higher education; and then a Table presenting a timeline of a wider range of relevant changes across the Century).

\section{Figures 3,4, and 5 (See Appendix)}

These are changes which, of course, fall very far short of what many of us still hope for, but which - particularly in the second half of the Century - may nonetheless justly be accounted nothing less than a quiet revolution. The contrast with criminalisation and imprisonment is extraordinary. Far from fulfilling the panicked prognostications of early criminologists such as Luke Owen Pike, ${ }^{21}$ who anticipated that women's liberation would lead to a surge in female crime, it looks as if, at least in relation to the more serious forms of offending which result in custodial sentences, the changes in women's official criminalisation have been modest, with even the proportionate rise in female violence shaped in part by a decline in levels

\footnotetext{
19 See Carol Smart, Women, Crime and Criminology op cit; see also Michele Burman and Loraine Gelsthorpe, 'Feminist criminology: inequalities, powerlessness and justice' (pp. 213-38); Jill Peay, 'Mental Health, Mental Disabilities, and crime' Ipp. 6** - 662); David Gadd, 'Domestic violence' (pp. 663-684); and Jo Phoenix, 'Prostitution and sex work' (pp. 685-703); Oxford Handbook of Criminology, $6^{\text {th }}$ edition (op. cit.)

${ }^{20}$ Bernard Harcourt, 'From the Asylum to the Prison: Rethinking the Incarceration Revolution' (2006) 84 Texas Law Review 1751; Eoin O'Sullivan and Ian O'Donnell, 'Coercive confinement in the Republic of Ireland: The waning of a culture of control' 9 Punishment and Society 27-48 (2007).

${ }^{21}$ Luke Owen Pike, A History of Crime in England Volumes 1 and 2 (London: Smith, Elder and Co., 18731876).
} 
of male violence rather than any decisive change in female behaviour. ${ }^{22}$ And while it is easy to satirize the fears on this count which plagued the late Victorian and Edwardian male imagination, there does seem to be something important to be explained about why the huge social changes in women's legal, economic and political position during the $20^{\text {th }}$ Century appear not to have been felt to anything like a proportionate degree in the criminal process. To unravel this question, I will suggest that it is helpful to put legal and literary resources into dialogue with one another.

\section{AGENCY AND RESPONSIBILITY IN 20TH CENTURY LAW AND LITERATURE}

Turning to that task, I must immediately confront and deal with some methodological challenges which confront any attempt to extend a legal and literary analysis of women's agency and criminality from the $19^{\text {th }}$ into the $20^{\text {th }}$ Century. The first complication is simply that the field of cultural representation has burgeoned during the last century, prompted by both technological change and economically and politically driven developments such as increasing prosperity and education. Whereas it was easy to justify a focus on literary fiction as one of the most significant forms of cultural representation in the $18^{\text {th }}$ and $19^{\text {th }}$ Centuries, printed fiction competes in the $20^{\text {th }}$ Century with radio and television series and feature films - to name just three comparable narrative forms - as well as with the theatrical and visual arts which were already significant in earlier centuries.

Moreover, while it was reasonably easy to distinguish a recognisable genre of literary fiction - realism - in the $18^{\text {th }}$ Century, even in the $19^{\text {th }}$, the genre was diversifying as the Gothic novel produced offshoots such as sensation fiction and science fiction. There was, of course, a debate, to which authors like Charles Dickens and Wilkie Collins contributed, about whether these distinctions were meaningful, but that need not concern us here. What is obvious, and has made selecting a sample of fiction far more difficult for the $20^{\text {th }}$ Century, is that this diversification has continued apace, with specialist genres such as detective fiction, crime novels, so-called 'chick lit', magical realism, postmodernism, proliferating at an ever-greater rate during the course of the Century. So, even restricting myself to British and Irish novels - as I have done, so as to remain consistent with the sample from my 2008 book - the choice is vast. I cannot claim to have been able to produce a very scientific way of defining the literature on which I am focusing, other than to say that it is the sort of work which might well find its way on to a Booker Prize list, and must have a distinctly realist ambition. Justifying the focus on books rather than soap operas or films seems easier to me, given that the latter developed after the

\footnotetext{
22 Greg T. Smith, 'Long Term Trends in Female and Male Involvement in Crime' 139 in Gartner and McCarthy (eds)
} 
beginning of the century, and have accumulated in reach and importance since the 1960s. But it should be acknowledged at the outset that my effort in this paper is a very small part of a potential project which would consider the changing legal and cultural constructions of women behaving badly in a wider range of cultural forms, with crime and detective fiction, film and soap operas a potentially fruitful terrain which has indeed already begun to be mined by imaginative criminologists, literary and media scholars. ${ }^{23}$

The second methodological challenge, which I had not anticipated, is this: When I started researching and brainstorming with friends and colleagues about a sample of books for my original project, it was extremely easy to come up with a list of realist novels in which women were central characters and were moreover centrally engaged in, if not criminal, at least counter-normative or strongly agentic behaviour. Indeed, many of them had given their names to the novels in which they appeared: Defoe's Roxana (1724); Richardson's Pamela (1740) and Clarissa (1747-8); Fielding's Amelia (1751); Burney's Evelina (1778), Cecilia (1782) and Camilla (1796); Wollstonecraft's Maria (1798); Edgeworth's Belinda (1801); Austen's Emma (1815); Charlotte Bronte's Jane Eyre (1847) and Shirley (1849); Gaskell's Mary Barton (1859); Oliphant's Hester (1883). Curiously, and I think significantly, it has proved much harder to identify $20^{\text {th }}$ Century literary fiction in which women are both central characters and counter-cultural if not criminal. Indeed, as we shall see, some of the most central, powerful and counter-cultural female characters in $20^{\text {th }}$ Century realist fiction are portrayed as in some way involved or collusive in their own victimisation.

I should, however, have anticipated this second problem, because I now see that it relates very closely to a third, which on the face of it could have been fatal to the enterprise of this paper. This is the explosion of literary modernism in the early part of the $20^{\text {th }}$ Century, which in fundamentally reshaping the form and, arguably, function of the novel, fractured the close analogy between the representational and indeed didactic or ethical purposes which the novel and the criminal law had arguably shared since the early $18^{\text {th }}$ Century. In light of modernism, with it radical questioning of the veracity of literary representations, of the unity of coherence of the subject, and of the knowability of self and others, influential legal/literary scholars including Jan-Melissa Schramm ${ }^{24}$ and Alexander Welsh ${ }^{25}$ have concluded that the disanalogies between law and literature become such that a certain kind of legal/literary interpretive project no longer makes sense.

\footnotetext{
${ }^{23}$ See for example, Alison Young, Imagining Crime: Textual Outlaws and Criminal Conversations (London: Sage 1995); Richard Sparks, Television and the Drama of Crime (Milton Keynes: Open University Press 1992); Ngaire Naffine, Feminism and Criminology op. cit.; Neil McCaw, Adapting Detective Fiction,: Crime, Englishness and the TV Detectives (London: Bloomsbury 2011).; R. Surette, Media, Crime and Criminal Justice (1998: $5^{\text {th }}$ edition 2015: Cengage Learning); Melanie Williams, Empty Justice: One Hundred Years of Law, Literature and Philosopby (London: Cavendish Press 2002); Kieran Dolin, A Critical Introduction to Law and Literature (Cambridge University Press 2007).

${ }^{24}$ Jan-Melissa Schramm, Testimony and Advocacy in Victorian Law, Literature and Theology (Cambridge University Press 2000).

25 Alexander Welsh, Strong Representations: Narrative and Circumstantial Evidence (Baltimore: Johns Hopkins University Press 1992).
} 
Here I would agree with Rex Ferguson's argument in his persuasive Criminal Law and the Modernist Novel, ${ }^{26}$ that, despite important emerging differences in the form and function of literature in the first three decades of the $20^{\text {th }}$ Century, the analogies between both the problems which law and literary authors confronted, and the ways in which they resolved them, are sufficiently close to sustain a meaningful project of interdisciplinary analysis. To understand why this is the case, we need to look in some further detail at the relevant shifts and trends in the construction of subjecthood, agency and responsibility in literature, in the criminal process, and in the criminal law.

Let us start with the criminal law. As I have already suggested, the 19th Century's systematising and modernising project, with its gradual construction of doctrinal rules constituting the responsible subject of criminal law in certain ways, and of protocols and institutions capable of testing and refining these doctrinal rules, was coming to fruition at the turn of the Century, with notable developments including the revival of the possibility of the accused testifying in her own defence in the 1898 Criminal Evidence Act, and the creation of the Court of Appeal in 1908. With regular professional representation of both sides in serious criminal cases, and a growing body of systematic literature in the form of treatises and textbooks, doctrines of mens rea and defence were gradually constituting the subjective responsibility of a person with normal cognitive and volitional capacities for the conduct elements of an offence as the paradigm condition for conviction - and one moreover which, as $W_{\text {oolmington }}{ }^{7}$ confirmed definitively in 1935 , the state had the burden of proving beyond reasonable doubt in all its elements. A system based on the trial as a process for inculpation, rather than an opportunity for exculpation, was being consolidated during this period, with presumptions such as that a person intended any natural consequences of their actions slowly being reconstructed as evidential rather than conclusive legal mechanisms. Strict liability offences based on causal outcome responsibility were growing in number and significance, but occupied a marginal place in the central ideology of the criminal law, which was increasingly focused on capacity responsibility, particularly in its subjective form, as both a legitimating and a coordinating device.

On the face of it, this move to subjectivism in the criminal law presents both analogies and disanalogies with the constitution of the subject in literary modernism. On the one hand, the centrality of subjective experience and of psychological states to the meaning of action and indeed the interpretation of the world is central to both legal subjectivism and the intense turn away from representation and towards expression of experience in writers like Henry James, Virginia Woolf or James Joyce. On the other hand, the legitimating and coordinating function of the principle of subjectivism in the criminal law seems to turn on an assumption about the unity of the subject and its knowability and transparency - both to the subject herself and to

26 Cambridge University Press 2013.

${ }^{27} D P P v$ Woolmington, [1935] UKHL 1. 
others, notably police officers and members of a jury - which, as we shall see, is under sustained challenge in the novel of this period. The law, indeed, continued with its systematising - confusingly given the literary language - process of 'modernisation', undeterred by the surrounding crisis of authority and social disruptions of the late $19^{\text {th }}$ and early $20^{\text {th }}$ Century. In literature, authors - particularly those writing from an, in some sense, émigré or outsider perspective, whether because of their national origins or their gender or social status - seized on this crisis of authority to put the very projects of truth, reason and transparency into question. By contrast, the law, with its concrete regulatory and power-imposing tasks, did not enjoy the luxury of exploring the metaphysical crisis which arguably underpinned the moments of obscurity, multiplicity, unpredictability, insanity, fragmentation, impenetrability or incomprehensibility pervasive in novels of the period, and instead turned to the construction of a range of protocols and institutional arrangements which allowed that regulatory, controlling and normative project to continue. Subjectivism and psychology, which bore the weight of the collapse of meaning and predictability in the novel, became the engine through which knowledge and truth was constructed in the law. They were, however, as we shall see, regimes of knowledge and truth in which women were incompletely accommodated.

Indeed, in both law and literature these modernising projects - whether of the construction or the subversion of the responsible subject - were ones in which women were either incompletely, or differentially, inserted. And in both fields, assumptions about subjectivity or its collapse were strongly overlaid with gender norms and assumptions. In the criminal law, women's assertion of subjectivity was - other than in a small number of female-gendered offences - almost definitionally tied up with a breach of gender norms, and hence tended to attract either a move towards pathologisation in the form, for example, of a mental incapacity explanation or defence; or a reading of 'double deviance': a breach of the criminal law and a breach of femininity. As Hilary Allen nicely put it, criminal law has struggled to place women as 'reasonable persons'. ${ }^{28}$ In literature, too, we find this divided tendency: an exaggerated experience of interiority of even mental collapse sits relatively easily with femaleness (Virginia Woolf's Mrs Dalloway (1924); Sylvia Tietjens of Ford Madox Ford's Parade's End 1924-1928); Doris Lessing's Martha Quest of the Children of Violence series (1952-1969)); while rational female agency, particularly where combined with a successful presence in social spaces beyond domesticity, such as work, invites a particularly punitive interpretation. Both legal and literary tendencies are tellingly brought together in F. Tennyson Jesse's $A$ Pin to See the Peepshow (1934), in which Julia Almond ${ }^{29}$ has her motivations interpreted by lawyers, judge and jury through the lens of gendered stereotypes about the deceptiveness of a woman determined to escape her husband and protect her lover - a narrative structure

${ }^{28}$ Hilary Allen, 'One Law for All Reasonable Persons?' 16 International Journal of the Sociology of Law (1988) 419-32; see also Allen, Justice Unbalanced op cit.

${ }^{29}$ Almond is based on the real (and convicted) murder defendant Edith Thompson. 
which bears a striking, and rather dispiriting, resemblance to the much more recent portrayal of Yvonne Carmichael in Louise Doughty's Apple Tree Yard (2013).30

In a range of ways, as Lindsay Farmer has argued, ${ }^{31}$ and as I have also shown in earlier work, ${ }^{32}$ the move to a subjective version of capacity responsibility implied a dualism in the criminal law as between responsible subjecthood on the one hand, and the conduct for which responsibility was attributed on the other. And this in turn implied a certain de-moralisation of the criminal law - or at least a projection of the site of judgment onto conduct as opposed to responsibility, which was now constructed in factual, psychological, non-moral terms. ${ }^{33}$ This means that any study of the literature of this period must focus as much on the forms of conduct for which women are held responsible as on the assumptions about their responsible agency which accompany them. Moreover this 'factualisation' or 'demoralisation' of responsible agency underwrites another analogy between law and literature in this period. For it is prompted by a discomfort with judgment which is a counterpart of the scepticism about judgment which was pervasive in the novel. In addition, the crisis of truth and judgement found in the modernist novel realises itself in the consequential reliance in the law on either a jury's interpretation of testamentary narrative or its evaluation of expert evidence, each of which produces its own epistemological uncertainties which the law does not resolve, but rather glosses over through the mechanism of jury secrecy. ${ }^{34}$ Unable to refuse judgment in the style of the novel, the law displaced it onto the secret deliberations of a lay jury or the inscrutable expertise of an expert. The law's vulnerability here is perhaps exposed most clearly in cases in which mental incapacity is put at issue in the trial: a position into which a disproportionate number of women offenders fall..$^{35}$

These analogies between the situation of criminal justice and that of the modernist novel of the early $20^{\text {th }}$ Century can be further appreciated if we supplement our vision of the criminal law with that of the criminal and penal processes which surrounded it. In the late $19^{\text {th }}$ Century, as the criminal classification statutes attest, the essentialised, biological view of crime to be found in the positivist criminology of Lombroso and Ferrero ${ }^{36}$ was itself shaping criminalising and penal arrangements in the form of mechanisms which certainly made bold (indeed, from our perspective outrageous) claims to 'truth'. But in the early 20th Century, this notion of biological pathology was beginning to give place to a vision shaped rather by notions of social pathology: with the acceptance that social and economic

${ }^{30}$ Note, however, one significant difference: while Julia Almond is convicted as an accomplice to murder, Yvonne Carmichael is acquitted of homicide and convicted of perjury, arguably signalling that by the early $21^{\text {st }}$ Century the very sexualisation of the crime, while further damaging her credibility, underpins her fundamental lack of perceived dangerousness.

31 Making the Modern Criminal Law: Criminalization and Civil Order (Oxford University Press 2016).

32 In Search of Responsibility op cit.

${ }^{33}$ Farmer 2016 op cit; Lacey 2016 op cit; cf. Alan Norrie, Crime, Reason and History (3 ${ }^{\text {rd }}$ edition, Cambridge University Press 2014).

34 op cit

35 Hilary Allen op cit; Susan Edwards, Women on Trial (Manchester University Press 1984).

36 C. Lombroso and W. Ferrero The Female Offender (Unwin: London 1895). 
circumstances constituted important determinants of criminal conduct. ${ }^{37}$ This socially deterministic vision was deeply threatening to the very notion of a responsible subject or the notion of stable character, and it echoed the focus in literary fiction on the role of environment in shaping both personality and conduct. Of course, the influence of biological theories did not disappear overnight either in criminal justice or in literature (think of the strange combination of biologism and social analysis which underpins Henry James' portrayal of Kate Croy in The Wings of the Dove, (1902) Radclyffe Hall's analysis of lesbianism in The Well of Loneliness (1928); or D.H. Lawrence's view of sexuality in Lady Chatterley's Lover (1928)). Hence, biological and social theories enjoyed an extended period of uncomfortable cohabitation - albeit with women remaining disproportionately situated within the biological interpretation. The way in which the criminal process managed the resulting tensions was through a division of labour between the criminal law and the penal process, which became increasingly constructed around what David Garland has called 'penal welfarism'; 38 in other words, the assumption that the penal and other arrangements should be designed in terms of manipulating offenders' environment so as to maximise the chances of reform and change. Within this distinctive configuration, criminal justice institutions were closely articulated with emerging mental health and social welfare institutions in a quite new constellation of institutions and discourses emerging from the Victorian ameliorative projects: institutions and discourse which were markedly less retributive but no less paternalistic than their Victorian predecessors. In penal welfarism as in criminal law, a turn to reliance on scientific expertise provided a partial solution to problems of legitimation and coordination while, as we shall see, storing up epistemological difficulties similar to those being explored in the modernist novel. And in a time lag which characterises the relationship between literature and law throughout the Century, those difficulties made themselves felt more fully in the criminal justice system in the second half of the Century. Meanwhile, the specifically gendered qualities of the emerging forms of penal welfarism, particularly in relation to female delinquency and mental incapacity, exaggerated an existing cultural tendency to label women's counter-normative behaviour in terms of illness rather than oppositional responsible agency. While - perhaps significantly - recorded in relation to a man (Septimus Smith, a victim of shellshock), the invincible, patriarchal rationality of the scientific authority which legitimised these judgments is bitingly criticised in Virginia Woolf's Mrs Dalloway (1924).

Finally, in terms of the analogies between literary fiction and criminal law during this period, we should note that, just as the law was itself having to negotiate certain challenges to authority and epistemological perplexities similar to those explored in depth in the modernist novel, doing so by developing its own distinctive

\footnotetext{
${ }^{37}$ Smart, Women, Crime and Criminology op. cit Chapter 2; Heidensohn, Women and Crime op. cit. Chapter 6.

${ }^{38}$ David Garland, Punishment and Welfare (Aldershot: Gower 1985); The Culture of Control (Oxford University Press 2001).
} 
protocols as well by an increasing turn to the truths constructed by scientific discourses, conversely, the novel never entirely abandoned its representational and interpretive roles. Certainly, modernist novels deliberately eschewed the aesthetic of linearity, progress and narrative closure which characterise the great realist novels of the $19^{\text {th }}$ Century; they also, as we have seen, pondered the multiplicity, fragmentation and instability of the self. But, as Terry Eagleton has noted, ${ }^{39}$ the move can never be complete: individual agency reasserts itself in forms such as resistance to plot line, and the explorations of fragmented consciousness typical of, say, Virginia Woolf, or the disjointed quotidian 'epiphanies' recounted in James Joyce, themselves partake in a certain form of representation, a certain engagement with, and indeed interpretation of, human being and reality. Moreover, the analogy between the novel's ethical and the law's regulatory purposes still held. Woolf may have protested that politics should be separate from art, and that the world of the novel is brought into being simply by the novel itself. But few of her readers, contemporary or current, could possibly read Orlando (1928) or even Mrs Dalloway (1924) as politically innocent texts, artefacts which give us no vision of aspects of human being or dilemmas about how to live. ${ }^{40}$ Moreover Orlando as a character is vividly agentic, even amid the radically historically determined nature of her identity, and notably her gender identity. Think of Orlando's biting satire on the construction of gender, or Woolf's devastating depiction in Mrs Dalloway (1924) of Lady Bradshaw's disappearance, by way of marriage, into the maw of patriarchal power: as Woolf memorably puts it, 'Fifteen years ago she had gone under. It was nothing you could put your finger on; there had been no scene, no snap; only the slow sinking, waterlogged, of her will into his. ${ }^{41}$ Few instances of even high modernism exemplify the extremes of opacity and unknowability of the incident in the Marabar caves in E M Forster's A Passage to India - often cited as the paradigm instance of modernism's focus on the limits of knowledge. For example, Ford Madox Brown's trilogy, Parade's End (1924-28) combines a novel focused on representational family and social history with a moment-by-moment exploration of Christopher Tietjen's experience of emotional chaos, in the more subversive modernist style which characterises Ford's presentation of the radically unknowable Captain Ashburnham of The Good Soldier (1915).42 Moreover, while aspects of modernism doubtless touched much literary fiction during this period, a vast amount of fiction continued in a more straightforwardly realist vein. A key instance would be F. Tennyson Jesse's A Pin to See the Peepshow, published in 1934, and of great interest from our point of view because it is broadly based on the notorious murder case against Edith Thomson and Frederick Bywaters in 1922.

How do these trends in the construction of the responsible subject in criminal law, criminal justice and literary fiction proceed in the second half of the $20^{\text {th }}$ Century? As Eagleton has noted, the trauma of the Second World War did not

39 The English Novel: An Introduction (Oxford: Blackwell 2005).

40 Cf. Terry Eagleton, The English Novel op. cit. 313

41 Kindle edition, Harper Perennial Classics 2013 p.118.

42 On which see Rex Ferguson, Criminal Law and the Modernist Novel op cit. Chapter 3. 
unleash anything like the explosion of a radically new form of literary fiction such as the modernism created by the émigré or otherwise 'outsider' writers of the early $20^{\text {th }}$ Century. One can only speculate on the reasons for this: perhaps one factor was the sense that, unlike the First World War, the Second World War had been unavoidable and fought in a just cause; another that the subsequent change of government to a (Labour) administration with an ambitious agenda of national renewal led to a more optimistic cultural ambience. Whatever the reason, literary fiction of the second half of the Century settled back into a primarily realist and representational mode, albeit with further diversification of genres - notably a burgeoning of specifically crime and detective fiction - and some significant points of innovation, again coming from new voices in some sense from the margins in either racial, colonial, sexuality or gender terms - postcolonial and feminist novels being key examples. ${ }^{43} \mathrm{New}$ forms of subjectivity were explored and, to some extent, normalised - particularly in terms of sexuality and gender identity (in for example Jeanette Winterson's Oranges are Not the Only Fruit (1985) or Jackie Kay's Trumpet (1998). But the conscious, capable and responsible subject more or less returns to centre stage, her character development and her ability to learn from cumulative experiences once again the primary focus of literary fiction. In general, the terrain of literary fiction contracts, concentrating itself upon emotional and domestic dramas. Significantly from our point of view, however, in the latter part of the Century, we can identify some key literary figures who seem to represent an interesting amalgam of environmentally produced deviance with older tropes of bad character or even evil - a trend nicely evoked by Fay Weldon's Life and Loves of a She-Devil (1983), considered in more detail below; and the more ambitious work of Angela Carter, which, in a manner reminiscent of Woolf's Orlando (1924), reaches for the tools of fantasy to express a vision of fluid, elusive identity, and to conjure a world in which gender, identity and even time are radically in question. ${ }^{44}$

Developments in criminal law and criminal justice to some extent diverge in the post-Second World War era. Until the last two decades of the Century, the criminal law continued on its path towards a systematic 'general part' consisting of principles applying across the offences - as epitomised by Glanville Williams' key 1953 text, Criminal Law: The General Part. ${ }^{45}$ The field also saw some significant efforts at substantive systematisation, for example in the Theft Act 1968 and the construction of a category of sexual offences in the Sexual Offences Act 1956. Hence, the myth of the gender-neutral legal subject persisted - disrupted only occasionally, as in cases such as Thornton ${ }^{46}$ and Abluwalia in the field of women's self-defence, which put the reality of gendered power relations at the heart of doctrinal argument. But the 1960s and 1970s saw, in criminal justice, developments

43 Key examples include Doris Lessing's Cbildren of Violence series (1952-69); Jackie Kay's Trumpet (1998); Zadie Smith's White Teeth (2000) and Andrea Levy's Small Island (2004).

44 See for example Nights at the Circus (1984) and the more dystopian The Passion of New Eve (1977).

45 London: Stevens and Sons 1953: second edition, 1961.

${ }^{46} \mathrm{R} v$ Thornton [1996] 1 WLR 1174; R v Abluwalia 1993) 96 Cr App R 133. 
which reflect in quite a fascinating way, several decades later, a close analogue to the novel's epistemological crisis of the modernist period. As the treatment/cureoriented versions of penal welfarism, organised around the so-called 'rehabilitative ideal', gathered pace, tensions between the legal conception of a capable, choosing subject who could justly be held responsible, and a more deterministic vision of subjects and their conduct as shaped by social environment or mental pathology, came to a head. On the one hand, the more committed advocates of the rehabilitative and treatment ethic - Baroness Barbara Wootton key among them ${ }^{47}$ - followed through on the logic of a determinist ontology by arguing for an abandonment of the mens rea principle in criminal law, in effect implying the disappearance of the responsible subject and a shift in the trial process from judgment to diagnosis within an entirely forward-looking and scientifically driven model. Liberal proponents of the responsibility principle, notably H.L.A. Hart, ${ }^{48}$ defended a middle path, asserting the moral centrality of a requirement of proof of mens rea in most cases, while allowing the defences to recognise and accommodate situations in which the pressures or influences of environment, circumstance or illness were so great as to undermine even the relatively undemanding conditions of agency required by the criminal law.

But a more radical riposte to the Wootton position was also forming itself, and its realisation in some ways echoes what Eagleton sees as the novel's retreat into older ways of representing the world. ${ }^{49}$ Driven by anxiety about the excesses of state power implied by the myth of 'treatment', the implicit appeal to a vague norm of social health, and the consequent establishment of wide and hard to challenge official discretion on the part of parole boards, prison medics, social workers and others, a civil libertarian critique of the rehabilitative ideal gained ground, first in the United States and then in other countries, from the early 1970s on. ${ }^{50}$ But this civil libertarian reaction was not the only form which the rejection of the rehabilitative ideal took. Perhaps yet more significant was a strong reassertion of the moral centrality of a subject fully responsible for her wrongdoing, with criminal judgment reframed within a 'neoclassical' model of what Lindsay Farmer has called 'the punishable subject': ${ }^{51}$ a neo-retributive vision in which criminal responsibility is a projection of the moral conditions of justified punishment, themselves premised on individual moral desert. ${ }^{2}$ This strong 'remoralisation' of criminalisation and punishment has been widely reflected in western legal systems, including those of Britain, where punishment commensurate with desert - albeit accompanied by

47 Crime and the Criminal Law: Reflections of a Magistrate and Social Scientist (London: Steven and Sons 1963); Social Science and Social Pathology (London: Allen and Unwin 1959).

48 Punishment and Responsibility (Oxford: Clarendon Press 1968) (second edition, ed. John Gardner, 2008); see in particular Chapter 7, 'Punishment and the Elimination of Responsibility'.

49 The English Novel op cit 331-8.

50 American Friends' Service Committee: Struggle for Justice (1971); Andrew von Hirsch, Doing Justice (New York: Hilll and Wang 1976).

51 Making the Modern Criminal Law op cit 188-92.

${ }^{52}$ For a paradigm expression of a modern retributivist position, see Michael S. Moore, Placing Blame (Oxford University Press 1998). 
forward-looking concerns such as deterrence and incapacitation - has reasserted itself as the central principle of criminalisation, with legal doctrines of mens rea holding firmly to intentionality, knowledge and foresight as the paradigm conditions of responsibility, but articulated more closely with an evaluative judgment of the overall wrongfulness of the conduct in question.

This has not meant, however, that the appeal to science has been altogether abandoned. In cases of mental incapacity, of course, expert testimony has continued to underpin modifications of the responsibility principle, mainly via the defences. And in a significant development, we have seen the emergence of forms of preventive, pre-inchoate responsibilisation in areas such as terrorism and public disorder, which I have argued constitute a new form of character responsibility, albeit premised not primarily on bad character understood in terms of evil or wickedness but in terms of presentation of risk, with actuarial or clinical forms of risk assessment accordingly occupying an important place among contemporary legal form of responsibility attribution. Perceived dangerousness as measured by clinical or actuarial data or - worse - popular sentiment and fear, has become, particularly in certain areas of criminal law, the new form of bad character. ${ }^{53}$ And, as in the case of women's self-defence, as well as in the $18^{\text {th }}$ Century, the conceptions of what count as good and bad character are strongly shaped by social norms relative to gender, as to race and class. Significantly for our purposes, the forms of risk and danger which underpin the new hybrid patterns of responsibility-attribution tend not to be associated strongly with women: the real life Moll Flanders figures of the late $20^{\text {th }}$ Century, Myra Hindley or Rosemary West - this is a very inadequate analogy, for obvious reasons - tend to be involved in extreme violence, often associated with a powerful male figure and involving sexual cruelty, rather than with profit oriented business with a generous helping of sexual activity on the side... and they lend themselves to characterisation in the terms of evil or pathology, rather than remediable and putatively rational bad behaviour.

In criminology, too, we have seen some significant shifts in the ways in which criminality is imagined, represented and explained during this period. In some ways echoing literary modernism's focus on subjective experience - and perhaps enabled by the relative demoralisation of criminal law and factualisation of criminal responsibility - an important strand in the sociology of deviance from the 1960s onwards explored the lifeworld of the (invariably male) offender, in an almost existential celebration of the excitement of transgression, ${ }^{54}$ and a decisive rejection of remaining traces of the early criminological view of crime as pathology. In labelling theory, too, we saw a shift to a focus on the mechanisms of power through which criminalisation is constructed, and a move away from the assumption of crime as a unitary or natural phenomenon. This move was also encouraged by the feminist criminologies emerging from the late 1960s onwards, which mounted a

\footnotetext{
${ }^{53}$ Lacey, In Search of Criminal Responsibility op cit. 147-173.

${ }^{54}$ Heidensohn,op cit; Smart op cit.
} 
telling critique of the ways in which, particularly in relation to women, older, essentialist criminological assumptions continued to exert considerable power, particularly in those areas in which criminal law's gaze was trained specifically upon women - areas which make up a small part of officially recorded crime, but exert an enormous disciplinary force. ${ }^{55}$ More generally, feminist scholars pointed out that women simply continued to be ignored in most of the more thoroughly sociological genres of criminological scholarship, despite their use of methods and focus on forms of behaviour which should have made gender norms a central category of inquiry and analysis. This move in criminology towards the sociological analysis of the mechanisms of power, the cultural forces, the institutional structures and the socio-economic conditions which shape different forms of crime has led to a diversification of the field into a wide array of sub-genres. It has also implied a greater and greater division between legal and criminological analysis, with criminal law and criminal justice increasingly ideologically shaped by a moral ontology which is open to social science or other scrutiny in only strictly circumscribed ways. But it is important to note that, on each of the most plausible general criminological theories - those rooted in opportunity, those focused on the power of crimeinhibiting mechanisms of control, and those concerned with labelling -- one might have expected to see, particularly in the second half of the $20^{\text {th }}$ Century, significant changes in both women's offending and practices of naming/identifying it.

In accordance with both cultural and economic changes - notably increasing levels of education, the expansion of the academy, the development of technologies which make it easier to disseminate both academic and literary texts, as well as to produce new forms of fictional representation - both literary fiction and criminal justice diversified in the second half of the $20^{\text {th }}$ Century, making generalisation, the identification of patterns and the building of even speculative explanatory theses ever more perilous. And yet, as I hope to have shown, we can nonetheless identify some broad trends and analogies, as modernism is followed by a partial revival of realism, and penal welfarism is partially supplanted by a revived neoclassicism and a new form of focus on character. With these patterns in mind, let us know turn back to our principal topic - that of the light which a juxtaposition of legal and literary sources can shed on the understanding of women's crime.

\footnotetext{
55 Smart op cit; Naffine op cit; Phoenix, op. cit.; Emily Jackson, Regulating Reproduction: Law, Technology and Autonomy (Oxford: Hart Publishing 2001); Rosie Harding, Regulating Sexuality (London: Routledge 2011).
} 


\section{GENDER, POWER AND AGENCY IN TWENTIETH CENTURY LITERATURE: SEXUALITY AND DECEPTION; ECCENTRICS, MADWOMEN AND MURDEREES...}

Over the last eighteen months, I have been immersing myself in $20^{\text {th }}$ Century literary fiction of a broadly realist temper with an eye to looking at how women's agency, responsibility and terrain for action are being represented, and how this changes over time.

If we leave aside for the moment the criminal classification statutes, with their a-agentic, bad-character-oriented images of fallen women and inebriates, the headline story of female crime at the beginning of the Century was, of course, that of the suffragettes: a powerful, purposive and agentic image which must have been reinforced for contemporaries by the hunger strikes in which many imprisoned suffragettes engaged. And indeed, in the literary sphere, the Century starts promisingly enough in terms of literary depictions of female agency and countercultural capacity. A key example is Henry James' The Wings of the Dove (1902). In this absorbing - and devastating - book, the beautiful, damaged, ambitious and certainly very will-ful Kate Croy, rejecting the advantageous marriage prospects which her wealthy and controlling aunt has planned for her, becomes secretly engaged to the besotted, impecunious and far less psychologically powerful Morton Densher, whom she then manipulates into deceiving terminally ill heiress Millie Theale that he is in love with her. Millie, a quietly powerful figure in her own right, discovers the truth, but nonetheless - we are led to believe - in an extraordinary, and extraordinarily self-denying, act of love -or is it of revenge, or perhaps resignation? - leaves her fortune to him. Kate and Morton now have the means to marry. But though Kate has won her dangerous game, she has also lost: their relationship is polluted, and, in modernist style, James gives us a vivid sense of the very self - that of Morton - dissolving, and then resisting, under the pressure of the moral dilemma which Kate's - and his own - distortion of his moral integrity entails. As for Kate, she hovers in James' portrayal, a beautiful, troubling metaphor for fin de siècle perplexity about women's social position: highly capable and agentic, but damaged by a toxic mix of indulgence and neglect. A dutiful daughter of a manipulative and degenerate father, a hint of the genetic inheritance so central to the criminology of the time is eclipsed in James' portrayal by the shaping force of the gender and class norms, and the norms of filial obligation, which encase and constrain her. Kate is a luminously capable and agentic figure, but one with no real scope to exercise her considerable talents in a productive way. With a foot in both modernist and realist camps, this novel gives a vivid sense of female capacity and wilful agency, and of the exquisitely controlled terrain, shaped by legal norms and social conventions, over which women might exercise it at the very start of the $20^{\text {th }}$ Century.

Kate's deceptiveness echoes back to Victorian associations between feminine deviance and dishonesty - an association which, as we shall see, persists in both 
literary fiction and criminology. ${ }^{56}$ But her cruel and counterproductive conduct reaches beyond mere dishonesty, and if literary heroines had continued to develop in the mould of Kate Croy, one feels that the true descendants of Moll Flanders (though considerably more complex psychologically) would have been walking the pages of English novels far earlier and more frequently in the $20^{\text {th }}$ Century than they in fact were. Instead, Millie is perhaps a better bellwether for the literary fate of women: capable, yet often portrayed as complicit in their own victimisation, including through their very own agency. But Kate Croy nonetheless prefigures what turns out to be a pervasive feature of $20^{\text {th }}$ Century female literary deviance: her criminal or counter-cultural behaviour is framed, if not motivated, by love or sexual desire, and hence re-domesticated within the usual gender hierarchy. Think, for example, of Lawrence's Lady Chatterley (1928), who flouts strong social conventions of both class and gender to pursue her feelings for gamekeeper Mellors; ${ }^{57}$ or of Elizabeth Bowen's Stella Rodney from The Heat of the Day (1948) - well established in a secure and prestigious career, but willing to risk her emotional and material security, by shielding a sexual partner who is guilty of treason; or of Fay Weldon's Ruth of The Life and Loves of a She-Devil (1983), who indulges in a range of criminal conduct, much of it involving deception, as well as acts of positively Gothic selfharm, to revenge herself on her unfaithful husband and his sexual partner - using the norms of exaggerated femininity moreover to do so. By the early $21^{\text {st }}$ Century, this love motive can at least take lesbian form, as it does in Sarah Waters' The Paying Guest (2014), in which the hitherto appallingly dutiful Frances Wray sleepwalks millimetre by millimetre (with one enormous leap in between) into colluding in the concealment of a homicide committed by her lover. But the literary trope of female moral choice and action shaped - even distorted - by sexual passion remains remarkably constant. In fact, the painful depiction of constrained yet potentially destabilising female sexuality is remarkably consistent with that explored in Radclyffe Hall's Stephen Gordon of The Well of Loneliness (1928) - a book with strong intertextual resonance with Waters' novel in a number of ways, not least in its setting in the early $20^{\text {th }}$ Century and portrayal of a minor character with a close resemblance to Stephen Gordon..$^{58}$

\footnotetext{
56 'Could He Forgive Her? Gender, Agency and Women's Criminality in the Novels of Anthony

Trollope', in Martha C. Nussbaum and Alison Lacroix (eds.), Subversion and Sympatby: Gender, Law and the British Novel (Oxford University Press 2013) pp. 176-204

57 Likewise, the violent attempt or intention, respectively, of Hermione and Gudrun in D. H. Lawrence's Women in Love (1920) are motivated by their intense feelings for men, even though each of them is represented as having a certain independence, the first because of inherited wealth, the latter because she has a profession as a teacher and considerable skill and reputation as a sculptress. Indeed Gudrun, by throwing up her independence to follow Gerald, albeit temporarily, comes - knowingly - close to becoming a 'murderee'.

58 Indeed, the orientation of strong female characters towards men is reflected in literature well beyond the terrain of crime or even markedly counter-cultural behaviour. For example, Harriet, the central figure in Olivia Manning's Balkan Trilogy (1956 - 1964) and Levant Trilogy $(1977$ - 1980) - a strong figure and an educated woman - loyally follows in the path of her feckless husband Guy, even in the face of his callous self-centredness, and notwithstanding feeling that ' $[\mathrm{A}] \mathrm{mid}$ the bovine atmosphere of collegiate maleness she was just a skirt with a library book' (Kindle Phoenix Epub ISBN 9781446429532 Arrow Books/Random House edition, 2012, location 1360, Balkan Trilogy). Cf.
} 
This is most assuredly not to deny that there are developments in the English novel of key significance for understanding how agency, its gendering and the opportunities for exercising it are developing. Particularly in the early part of the Century, with the flourishing of literary modernism, the focus on the interior world of subjects, perhaps most especially female subjects, is striking. Indeed, in an exaggerated reflection of what was happening in terms of the psychologisation of ideas of criminal responsibility (and of criminal incapacity), interiority - echoing the deepening of psychological understandings of criminal responsibility - often virtually replaces or displaces plot. This is particularly striking in James Joyce's Ulysses (1922), particularly in Molly Bloom's famous soliloquy. And quite apart from exemplifying the novelistic turn to the psychic interior, the soliloquy is a fascinating commentary on gender difference. On the one hand, Molly's sense of self is saturated with the body and with sex, in a way reminiscent of the features of Lady Chatterley's Lover (1920) which make it uncomfortable reading for today's feminist. On the other hand, Molly is an astute commentator on men's combined arrogance, brutishness and fragility, repeatedly commenting on their need to appear to control things (and indeed implying their ineffectiveness in doing so...). In a lovely moment of irony, she describes a lover as an 'ignoramus that doesn't know poetry from a cabbage', 59 and conjectures that the world would go better if run by women.

Interiority, alongside a heightened sense of the self and it complex relation to the social, is also central of course to the tone and focus of Virginia Woolf's literary fiction in novels such as Mrs Dalloway (1925) and Orlando (1928). Indeed, Orlando explicitly ponders not only the social construction of gender ('She was becoming a little more modest, as women are, of their brains, and a little more vain, as women are, of her person'60) but also the multiplicity of the self. Indeed, in protopostmodern style brings the self into being as a question or a project rather than a represented discovery:

Orlando heaved a sigh of relief, lit a cigarette, and puffed for a minute or two in silence.

Then she called hesitatingly, as if the person she wanted might not be there, 'Orlando? For if there are (at a venture) seventy-six different times all ticking in the mind at once, how many different people are there not - Heaven help us - all having lodgment at one time or another in the human spirit? Some say two thousand and fifty-two.

Hervey Russell, a strong character at the centre of Storm Jameson's None Turn Back (1936): 'She had no ambitions of her own; if she shone, it must be in order to see some man roused and admiring. She felt convinced that she could help an ambitious man to be successful.' (Kindle edition, Bloomsbury Reader 2011, location 2580).

$598^{\text {th }}$ sentence of Molly Bloom's soliloquy at the end of Ulysses: Kindle Modern Classics Series, e-artnow 2016 ISBN 978-80-268-4984-1, location 13838.

60 Kindle edition Lettere Animate Classic, location 1770 
So that it is the most usual thing in the world for a person to call, directly they are alone, Orlando? (if that is one's name) meaning by that, Come, come! I'm sick to death of this particular self. I want another.

Hence, the astonishing changes we see in our friends. But it is not altogether plain sailing, either, for though one may say, as Orlando said (being out in the country and needing another self presumably) Orlando? still the Orlando she needs may not come; these selves of which we are built up, one on top of another, as plates are piled on a waiter's hand, have attachments elsewhere, sympathies, little constitutions and rights of their own, call them what you will (and for many of these things there is no name) so that one will only come if it is raining, another in a room with green curtains, another when Mrs Jones is not there, another if you can promise it a glass of wine - and so on; for everybody can multiply from his own experience the different terms which is different selves have made with him — and some are too wildly ridiculous to be mentioned in print at all. 61

Abutting the sense of the multiplicity and instability of the self, another theme which comes out of these and other novels of the pre-Second World War period is a preoccupation with mental instability and mental illness, and with the fragility of the line between mental health and mental illness, as well as a determination to explore the multiplicity and instability of the self in ways prefigured by some sensation fiction (e.g. Lady Audley's Secret (1862), The Woman in White (1859), but in an entirely fresh and far more subjective psychological form. In many novels of this period, the central characters - particularly though not exclusively the women - are engaged through the novel in a continuous intrapersonal dialogue in which various aspects of the self are explored and, more or, often, less successfully, brought into relation with one another. This strikes me as really fascinating in terms of its potential relationship to the law: on the face of it, the literary emergence of an unstable, decentred, multiple self of course poses challenges for the modern legal doctrines of subjective responsibility based on capacity, which were central to the penal welfarism of the first half of the $20^{\text {th }}$ Century. For such law operates of necessity with a paradigm of a unified self, capable of directing its actions and responding to the ameliorative motivations and incentives provided by the criminal justice system and other regulatory mechanisms. The nascent critique of a binary split between sanity and insanity with which several of these novels - Mrs Dalloway (1924) most clearly; but also later novels such as Antonia White's Frost in May (1933) and Beyond the Glass (1954), or Doris Lessing's The Four-Gated City (1969) and the Golden Notebook (1969) - engage is of particular interest from this point of view. Again, this is a luxury which the law, engaged as it is in a project of classification and judgment, cannot indulge: and yet it struggles with the very same dilemma in court rooms, legislatures and jury rooms, the essential unknowability of where the line should be drawn between sanity and madness being nicely underlined in Graham Macrae

61 Ibid location 2983-7 
Burnet's His Bloody Project (2015), which reconstructs the 'confession' and 'trial' of a $19^{\text {th }}$ Century crofter convicted of murder. Burnet's book is a telling reminder not only of the perplexity of the legal judgment of responsibility in such cases but, inversely, about gender and class: had the crofter been female, an insanity verdict might well have been easier to secure. Intersectionality is clearly a key issue here. In law, think of the difference between the construction of Kiranjit Ahluwalia and of Sara Thornton, ${ }^{62}$ both accused of killing their partners, as defendants - a difference strongly inflected by prevailing racial stereotypes. ${ }^{63}$

It also seems significant that Mrs Dalloway (1924), though just as central to the book as its title suggests, is identified not by her name but by her marital status unlike the gender-bending Orlando, whose transcendence of gender fixity, yet astute meditations on embodied gender difference as s/he experiences physical, social and emotional transition from one gender to another, renders the novel a key text in any attempt to understand the unfolding of ideas of sex and gender in the $20^{\text {th }}$ Century. In particular, Orlando's (1928) combined perception of the upsides of feminine identification/sociality and critique of the constraints on women is strikingly fresh almost a century after its publication. Though often thought of as an extended love letter, Orlando is also a seriously political novel: its portrayal of the social habitus and power structure of gender self-discipline is decades before its time - indeed positively Foucauldian. And it marks the emergence of radical idea of gender as a spectrum, as fluid - an idea which is arguably only coming to practical fruition in the western world in the early $21^{\text {st }}$ Century. Indeed, it is hard to come up with many $20^{\text {th }}$ Century novels with such an agentic and central (partially) female character, and many of those which followed Orlando portray even vivid and powerful female protagonists as in some sense pathetic, eccentric or marginalised: think, for example, of Elizabeth Taylor's egocentric and self-deluding novelist, Angel Deverell (1957); Muriel Spark's painfully brave yet out of touch Jean Brodie of The Prime of Miss Jean Brodie (1961). There is an interesting contrast here with Graham Greene's and Angela Carter's deliciously unapologetic (and occasionally criminal) eccentrics, Augusta Bertram and Nora and Dora Chance of, respectively, Travels with my Aunt (1969) and Wise Children (1991) - raising an interesting question as to whether the space to adopt an eccentric persona is the one, small piece of social space gained by late $20^{\text {th }}$ Century women, in an intriguing (dis)analogy with Moll Flanders' more straightforwardly deviant persona - even if one which tends to be created by authors who are reaching beyond the canons of literary realism.

This touches on a further significant theme which emerges from the novels: that many of the instances of deviant or sharply counter-cultural feminine agency in $20^{\text {th }}$ Century literature are women who have in some sense cast off or distanced themselves from a conventional femininity or even femaleness, while at the same

\footnotetext{
62 op cit note 46 above.

${ }^{63}$ D. Nicolson and R. Sanghvi, 'Battered women and provocation: the implications of $\mathrm{R} v$ Abluwalia (1993) Crim L R 728.
} 
time using all the techniques conventionally associated with the psychological mechanisms through which women are typically able to exercise power. Apart from Orlando, another very fascinating example is Elizabeth Bowen's Mme Fisher of The House in Paris (1926) - one of the most cruel and manipulative female figures in $20^{\text {th }}$ Century literature, and one whose relationship to femininity is at once emphasised and distanced. She exercises a key part of her power to manipulate and indeed destroy others psychologically through her role as a mother and through her preternaturally acute sense of other's psychic vulnerabilities; but her invalid status, age and widowhood render her relation to norms of sexualised femininity oblique. Also notable here is the co-optation of her almost impossibly dutiful and thoroughly damaged daughter, Naomi, in the exercise of her power, notwithstanding Naomi's recognition of 'evil' in the house: indeed both Naomi and Karen come close to being, like Max - and at least at a spiritual level - murderees, effaced by Mme Fisher's malign will. An Orlando-like meditation on the possibilities of gender fluidity re-emerges powerfully only with the luminous works of Angela Carter - notably in The Passion of New Eve (1977), with its layering of genders: turned from man to woman - a punishment for his brutality towards women? - Evelyn/Eve finds that 'Under the mask of maleness I wore another mask of femaleness but a mask that now I never would be able to remove... ', and in relation to the (in fact male) film star Tristessa in her gender-fluid character, notes that 'You and I, who inhabited false shapes, who appeared to one another doubly masked, like an ultimate mystification, were unknown even to ourselves. Circumstances had forced us both out of the selves into which we had been born, and now were were no longer human.' (1977: 129; 132). This play with gender and meditation on the relationship between gender or bodily form and human being also features in different ways in Nights at the Circus (1984) ('Am I fact? Or am I fiction? Am I what I know I am? Or am I what he thinks I am? (1984: 344) and The Infernal Desire Machines of Doctor Hoffman (1972). (Carter is also characteristically brisk about the potential motivations for female crime: in Nights at the Circus, the narrator notes that

'There are many reasons, most of them good ones, why a woman should want to murder her husband; homicide might be the only way for her to preserve a shred of dignity at a time, in a place, where women were deemed chattels or, in the famous analogy of Tolstoy, like wine bottles that might conveniently be smashed when their contents were consumed. No reasonable female would hold it against their Countess P. that she poisoned her husband' (1984: 247).)

But novelists tackling similar issues from a more conventionally realist method than Carter's have portrayed a world in which, notwithstanding the possibilities of crossing or mixing of gender identities, the norms remain as fixed - and as potentially brutal to those who transcend them - as ever. Here Jackie Kay's exceptionally eloquent Trumpet (1998), based on the real-life story of a jazz musician who lived as a man for the major part of his adult life, and whose 'exposure' as a woman causes huge psychic shock to his son, as well as a public scandal, after his 
death, is a paradigm - as, in a different register, is Jeanette Winterson's Oranges Are Not the Only Fruit (1985). In these books, deep questions are raised about why, respectively, gender and sexuality, are treated as so central to human identity and relationships. It is a theme on which literature has moved light years ahead of law. In an exemplary recent case, a young woman who had deceived another young woman into believing that she was a man, and then engaged in penetrative sex with her using a dildo, was convicted of sexual assault by penetration - an offence equivalent in seriousness to rape: it was more or less taken for granted that the deception as to sex/gender - unlike deceptions as to age, marital or health status, or an intention to pay, in a sex work context - was a fundamental issue going to consent: an offence so serious that it attracted a six and a half year custodial sentence. ${ }^{64}$

Of course, this might be taken to be a trivially definitional claim: criminal or quasi-criminal behaviour just is counter-cultural or counter-normative for women. But there are some striking instances of novelists exploring this relationship between resistance and conformity to gender and other social norms quite explicitly. The most moderate examples involve simple refusals to conform to prevailing norms of sexuality or marriage: Stella Rodney, Jean Brodie, Hilary Mantel's Alison Hart, the uncompromising psychic medium of Beyond Black (2005). But there are also more vivid or extreme examples. Here I find Ruth, Fay Weldon's initially physically unattractive, oppressed and highly intelligent housewife-turned- she devil interesting, particularly in those passages where she talks about needing to rid herself of her 'she-ness' in order effectively and by hyper-rationally-calculated (not to mention multiply criminal) means to revenge herself on her unfaithful husband. ${ }^{65}$ Weldon's 'she-devil' Ruth - perhaps an ironic play on Defoe's 'she-merchant', Roxana (1724) - engages in criminal conduct of which she is unashamed; and she draws on both her intelligence and hyper-conventional femininity to plan and execute it. Ironically, however, she draws on a number of stereotypically female capacities - domestic and child-rearing skills for example - to effect part of her revenge, and ultimately rebuilds herself a sexually attractive woman, through an exaggerated form of cosmetic surgery which shifts the novel from realism into fantasy, in the ultimate stages of her plot. ${ }^{66}$ So Ruth is only a very approximate

\footnotetext{
64 Simon Hattenstone and Helen Pidd. 'Gayle Newland found guilty at retrial of tricking female friend into sex' (The Guardian, 29 June 2017) < https://www.theguardian.com/uk-news/2017/jun/29/gaylenewland-found-guilty-at-retrial-of-tricking-female-friend-into-sex ; https://www.theguardian.com/uknews/2017/jul/20/gayle-newland-jailed-for-tricking-female-friend-into-sex $>$ accessed 18 September 12017.

65 See for example Kindle edition (Epub ISBN 978184894416 9: Hodder and Stoughton/Hatchette Livre UK 1984) pp. 48-9: Indeed, Ruth experiences her husband's labelling of her as a 'she-devil' as a liberation: 'if you are a she devil the mind clears at once. The spirits rise. There is no shame, no guilt, no dreary striving to be good. There is only, in the end, what you want. And I can take what I want. I am a she devil!'

${ }^{66}$ Weldon's sequel, Death of a She-Devil (2017) sees Ruth further punished by her own self-assertion, as the physical effects of her cosmetic surgery, her unreliable powers of judgement, and the perfidy of her associates sees the sisterhood which she has established implode in what can only be described as
} 
descendant of Moll Flanders. It is moreover worth noting that among her stereotypically feminine tools we must include a highly-developed capacity for deception - something which occupies, as I have already noted, a key place in instances of women's crime in crime fiction, with useful examples including Agatha Christie's Witness for the Prosecution (1925) and Louise Doughty's Apple Tree Yard (2013).

Indeed, as far as I have been able to discern, crime is exceptionally rare for female heroines beyond the specific genre of crime fiction, and even here, deception predominates as the quintessential characteristic of the female offender. Beyond crime fiction, though deviant behaviour and its temptations remain a theme of the novel, these are played out over a small canvass in terms of conduct - while a huge one in terms of emotions and interiority. As I argued in the previous section, the factualisation of mens rea in the early $20^{\text {th }}$ Century displaced the full weight of criminal evaluation onto the conduct element of offences, and hence the terrain over which female bad behaviour is motivated and takes place in literary fiction is arguably just as significant as literary representations of feminine subjectivity. Certainly, there are instances of cheerfully agentic female eccentricity spread across the Century: Winifred Holtby's South Riding (1936) features not one but two highly agentic and relatively untroubled female protagonists - head teacher Sarah Burton and Alderman Mrs Beddows (apparently modelled in part on feminist Holtby and her mother). Another luminous example is Angela Carter's Wise Children (1991), whose twin sister heroines, actresses Dora and Nora Chance, cheerfully breach armfuls of social norms without apparently suffering excessive levels of stress or encountering disaster. (They have a knack of turning disaster into carnival...). At the other end of the carnival spectrum - indeed a reversal of carnival into very dark terrain, we have Nicola Six of Martin Amis's London Fields (1987), in which a hypersexualised, thoroughly agentic but very damaged women uses her considerable rational and sexual powers to manipulate two men in such a way as to collude in her own death. Almost like Millie Theale, Nicola's role in the novel is that of 'murderee', as Amis puts it. ${ }^{67}$ Here he is echoing Lawrence's Birkin of Women in Love (1920), ${ }^{68}$ who is in turn echoed by Dinah, the unconventional younger sister in Rosamond Lehman's The Echoing Grove (1953), in which she identifies herself as having neared this role at various points in her life: 'Some women do get drawn into the aura [of other couples' 'nerve storms'], though. They get to be murderees. You can smell it

Gothic style. The novel is hard to interpret, but at best pessimistic about, and at worst contemptuous of, the feminism which might have been seen to inform the original book.

67 Beyond the specific purview of this paper, but a feature of London Fields which cannot escape comment in any feminist text, is Amis's equation, in Keith's persona, of femaleness with rapability: see for example Kindle edition Epub ISBN 9781409028710 Random House 2003: p. 168. It is an association which is also visited, in a more thoughtful and critical way, in Angela Carter's The Passion of New Eve, in the persona of Eve, who as a former man reconstructed as a woman, experiences a rape from, as it were, both gender subject positions: her rapist 'forced me to know myself as a former violator at the moment of my own violation. When he entered me, the act seemed to be one of seppuku, a ritual disembowelment I committed upon myself...) (Virago 1977, Kindle edition ISBN 978-0-34900-817-2: p. 98)

68 See Eagleton, The English Novel: An Introduction op cit. p. 263. 
in them. I know what you mean. I was pretty rank myself once.' ${ }^{\prime} 9$ The message is clear: a wilfully deviant woman can expect to be murdered. Nicola Six is a murderee who combines Millie's fatalism with Kate's wilful and cold resourcefulness. Bisecting the period which separates Kate from Nicola, Daphne du Maurier's immortal (in more than one sense) Rebecca (1938) provides another telling metaphor of $20^{\text {th }}$ Century literary fiction's preoccupation with the female murderee - indeed Rebecca's ultimate triumph over both her husband and her successor as Mrs de Winter stands as the epitome of $20^{\text {th }}$ Century female literary agency: her power is psychological, and is exercised through her hold over the minds of others; and her ultimate use of that power - resistant to the patriarchal structure within which her marriage has confined her though it may be - consists in an act of indirect selfdestruction. ${ }^{70}$ If this is progress in terms of the power of female agency, it is the very reverse in terms of the terrain over which, and the means by which, that agency is represented as being played out.

\section{CONCLUSION}

The main message from literary tradition through $20^{\text {th }}$ and into early $21^{\text {st }}$ Century from my reading so far is therefore that - in keeping with the still modest representation of women in the criminal courts and prisons of England and Wales - their literary representations and preoccupations remain remarkably constant and confined. Countercultural $20^{\text {th }}$ Century literary women exert a power which emerges from the personal, emotional, interior, psychological; which is motivated by relationships, romance and sexual jealousy which is effected by deception; which often features mental illness and breakdown; and which is invariably shaped by pressures within a family, sexual and patriarchal context. I am still reading, and would love to be directed to any good examples - particularly counter-examples to this interpretation. But as things stand, my interpretation is that parallels between literary and legal representations of women every bit as strong as those I found for the $18^{\text {th }}$ and $19^{\text {th }}$ Centuries, with literary history underlining the sense in which the changes in women's legal and political status and economic opportunities have not been accompanied by nearly such a vivid change in underlying constructions of gender difference. The harder edges of formal state control represented by the official crime and imprisonment figures need - happily - rarely be invoked. But this is for the ambivalent reason that they pale into insignificance alongside the informal discipline exerted by conventional gender norms and the power structures which

\footnotetext{
${ }^{69}$ Kindle edition, Virago ISBN 978-0-34900-428-0, location 5600/p.294

70 This is of course to say nothing of the other strongly counter-normative female figure in Rebecca: the powerful and sinister Mrs Danvers, who offers a paradigm of deceptive female literary deviance, and one in which there is more than a hint of (vicarious) erotic pleasure.
} 
sustain them. Sexualisation in particular remains a key means of denigration and control: indeed, ironically - and as perhaps reflected in social media assaults on women - it may have strengthened in the wake of the greater sexual freedom ostensibly accorded to women in recent decades. As women's undoubted progress in the worlds of work, politics and education continues, this under-representation may seem unimportant, indeed something to be celebrated. It would be absurd to regard a rise in women's representation among offenders as a salutary marker of gender equality. But we should remember that these same differences - related as they are to surrounding structures of power - may also be the very things which keep women radically under-represented in the very top echelons of business, political, legal and media worlds, and often - Hillary Clinton offers a vivid recent example - vilified and disrespected when they do so. Yet more importantly, in many parts of the world, they continue to expose women to disproportionate levels of poverty and sexual exploitation and make them vulnerable to violence.

This finding of a relatively modest imaginative terrain over which counternormative female behaviour is played out in the pages of realist literary fiction echoes, of course, the relatively modest changes in the gender ratio criminalisation and imprisonment during the course of the century. It echoes, moreover, the continuing marginalisation of women in criminology. A vigorous incursion of feminist analysis and argument into the field from the late 1960s to the end of the Century exposed the gendered assumptions which underpinned not only the intellectually discredited essentialism of early positivist criminology, but the troubling paternalism and sheer sexism of the differential treatment of female delinquents, through to the rank misogyny of the law, and/or the implementation of the law, on abortion, divorce, rape, incest, infanticide, prostitution, domestic violence, and the reactions of women confronted with the latter, often constructed in terms of mental incapacity defences rather than the more agentic framework of self-defence. But, forty years after the publication of Smart's pioneering Women, Crime and Criminology - indeed, almost unbelievably, half a century after Frances Heidensohn's key article in $1968^{71}$ - the field has proved resistant to the kind of integrated gender analysis which Smart persuasively argued to be needed to produce a discipline capable of truly shedding light on not only women's but men's behaviour and official reactions to it. Smart herself withdrew from the field in the late 1980s, arguing for a turn to back to sociology and to poststructuralist theory; many others, Heidensohn included, have fought on. Some progress, undoubtedly, has been made, not least in some tentative analyses of the relevance of masculinity to the conception, commission and interpretation of crime. But the complaint which Ngaire Naffine made in her Feminism and Criminology, ${ }^{72}$ published just before the close of the $20^{\text {th }}$ Century, retains some purchase today: while the latest edition of the influential Oxford Handbook of Criminology, ${ }^{73}$ edited by three scholars all of whom

71 Frances Heidensohn, 'The Deviance of Women: A critique and an enquiry', (1968) 19 British Journal of

72 Op cit

73 Op cit 
recognise the relevance of gender to crime and criminalisation, features three essays with specific reference to feminism, gender and crime, as well as a range of references to women, gender and feminist criminology, the majority of these references are to those three chapters, leaving the rest of its 1056 pages $^{74}$ predominantly if implicitly concerned with men. Criminology remains fascinated by why people commit crimes, rather than by why they do not - an obvious question, one would have thought, given the pervasive inequality which might be thought to make at least some kinds of crime a serious temptation to women as much as, and indeed, given economic gender inequality, perhaps more than, to men. Hence criminology is significantly more interested in men than women. In criminological terms, while, ostensibly, women's opportunities have increased, their capacity to take them up remains differentially constrained by informal social controls confirming Feeley and Aviram's speculation that the private patriarchy which shaped the decline of women in the criminal process in the late $18^{\text {th }}$ and $19^{\text {th }}$ Centuries has survived the $20^{\text {th }}$ to a greater degree than one might have expected. Moreover, these same gender norms doubtless have effects - exaggerated though the so-called 'leniency hypothesis' about reluctance to criminalise women may often have been - on gendering the social construction of crime by officials and members of the public.

In terms, finally, of my explanatory argument about the re-emergence of character responsibility in the late $20^{\text {th }}$ Century - a development which we might expect to have some significance to gender patterns of responsibility-attribution, some intriguing possible hypotheses about these connections present themselves. One of them is this: To the extent that the huge economic shocks of the 1970s and since, along with the social changes which they brought in their wake, have affected the status system which I argued in Women Crime and Character to have been a key part of what shaped legal and literary patterns of female deviance, that realignment of status has in some ways increased women's status at the expense of men's. (Think, for example, of the figures on education and, though more complicated, on employment: see Figure 4 of the Appendix). Arguably, unpleasant phenomena such as the increasing harassment of women on social media is, to some extent, a backlash against this realignment of gender opportunities and status. In other words, women's material progress has called forth an intensification of informal social control. In criminal justice, the new forms of character-assisted mechanisms of responsibility attribution are themselves particularly targeted at forms of conduct which remain male-dominated (itself, of course, a matter to be explained). So one broad possibility would be that the (relative, and still far from complete) gains made by women are either reinforcing incentives for women not to offend, and diminishing fears about women's crime; and doing exactly the reverse for men (particularly, of course, some groups of men). The emerging hybrid pattern of bad

${ }^{74}$ Including the chapter of which I am a co-author: on the challenge of integrating gender analysis, see Nicola Lacey, 'In Dialogue with Criminal Responsibility' Critical Analysis of Law 4:1 (2017). 
character and risk invokes an image of dangerousness from which women are insulated by prevailing gender norms. If only one could regard this as an unambiguously good thing...

Whatever the truth of this preliminary interpretation, one point - at once methodological and substantive - emerges. The relative stability of the gender patterns of criminalisation over the course of the $20^{\text {th }}$ Century suggest that material changes themselves are an incomplete explanation of the development of the social phenomena of criminalisation and punishment over time. What cultural forms such as literary fiction help us to appreciate is the key role played by gender norms, expectations and assumptions in shaping human judgment or behaviour: that of people defining rules and conventions; that of those breaching established rules and conventions; and that of those interpreting and responding to perceived breaches. As well as a case study in the potential for bringing law, criminal justice studies and literature, the social sciences and the humanities, into dialogue, then, I offer this paper as a case study in the pitfalls of the prevailing tendency in the social sciences to separate out, within any one piece of scholarship, quantitative methods and qualitative methods; and to separate questions of material power and interest, from questions of culture. Bringing these different questions and methods together does not produce the clear results beloved of an academy increasingly obsessed with auditing and ranking. But it is the only way to begin to tackle the large questions which, surely, justify the existence of an academy worthy of the name. 
Figure 1.1. Female prison population in England and Wales, 1900 - 2015

5,000

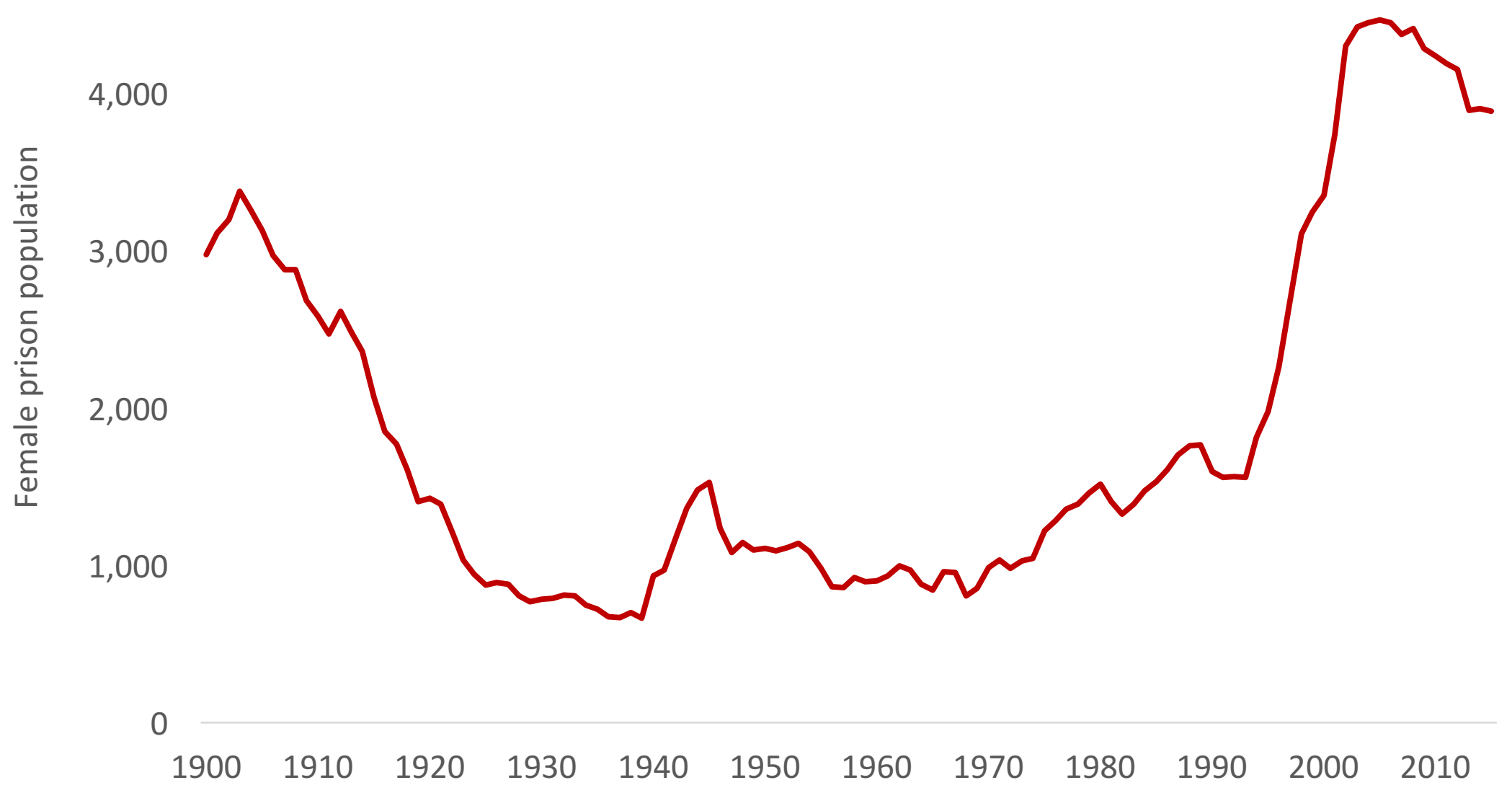

Source: Allen, G., \& Dempsey, N. (2016). Prison Population Statistics. House of Commons Library Briefing Paper, No. SN/SG/04334, 4 July 2016. 
Figure 1.2. Female prison population (as a \% of total prison population) and female prisoners (per 100,000 of the female population) in England and Wales, $1900-2015$

$20 \%$

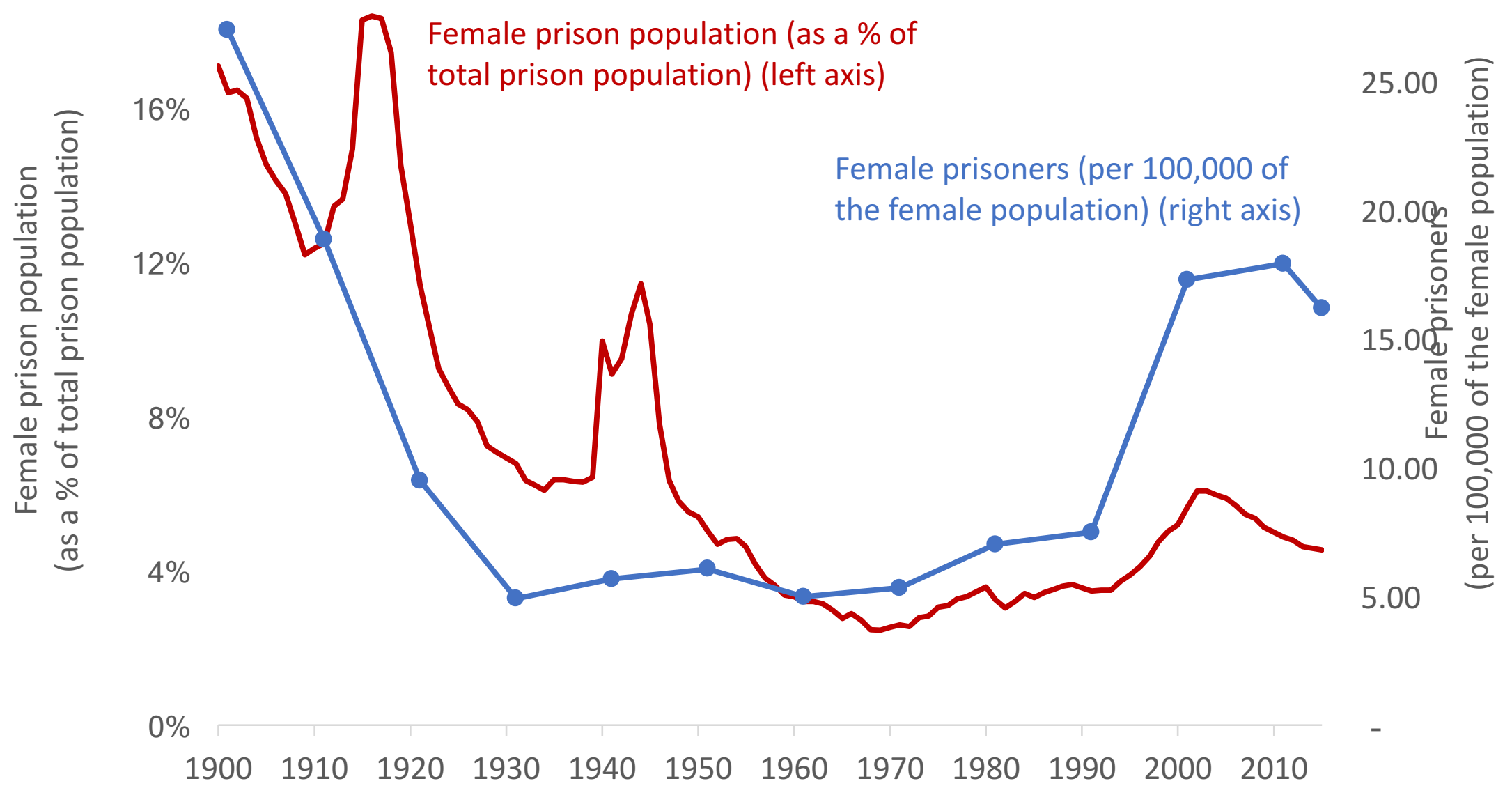

Source: Author's calculations; Allen, G., \& Dempsey, N. (2016). Prison Population Statistics. House of Commons Library Briefing Paper, No. SN/SG/04334, 4 July 2016. 
Figure 2.1. Women as a \% of offenders found guilty for violence against the person in England and Wales, 1901 - 2011

$25 \%$
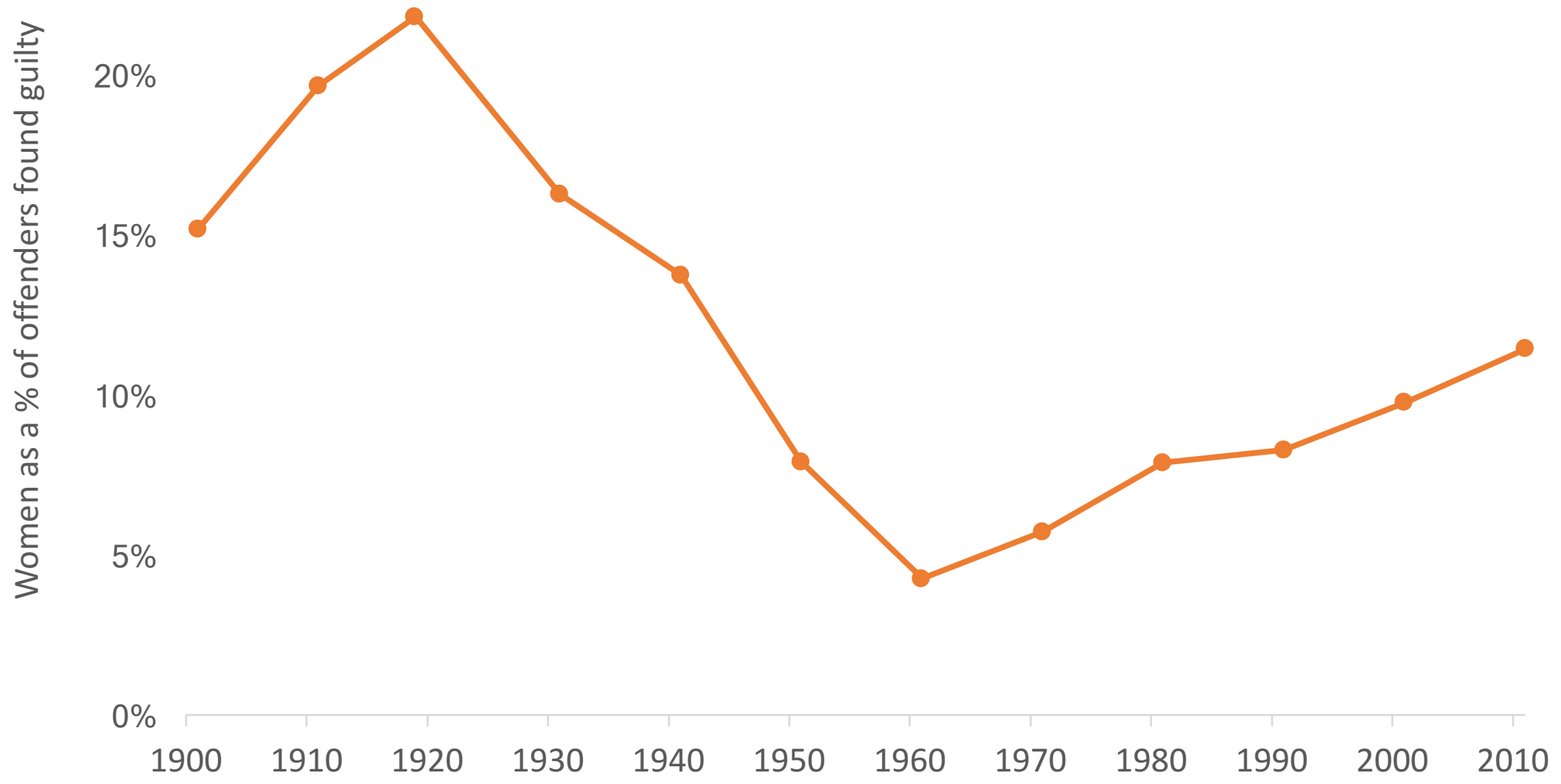

Source: Author's calculations; Home Office Criminal Statistics, England and Wales (various years); Ministry of Justice, Criminal Justice System statistics quarterly, England and Wales. 
Figure 2.2. Women as a \% of offenders found guilty for offences against property and forgery (excluding burglary and extortion) in England and Wales, 1901 - 2011

$25 \%$
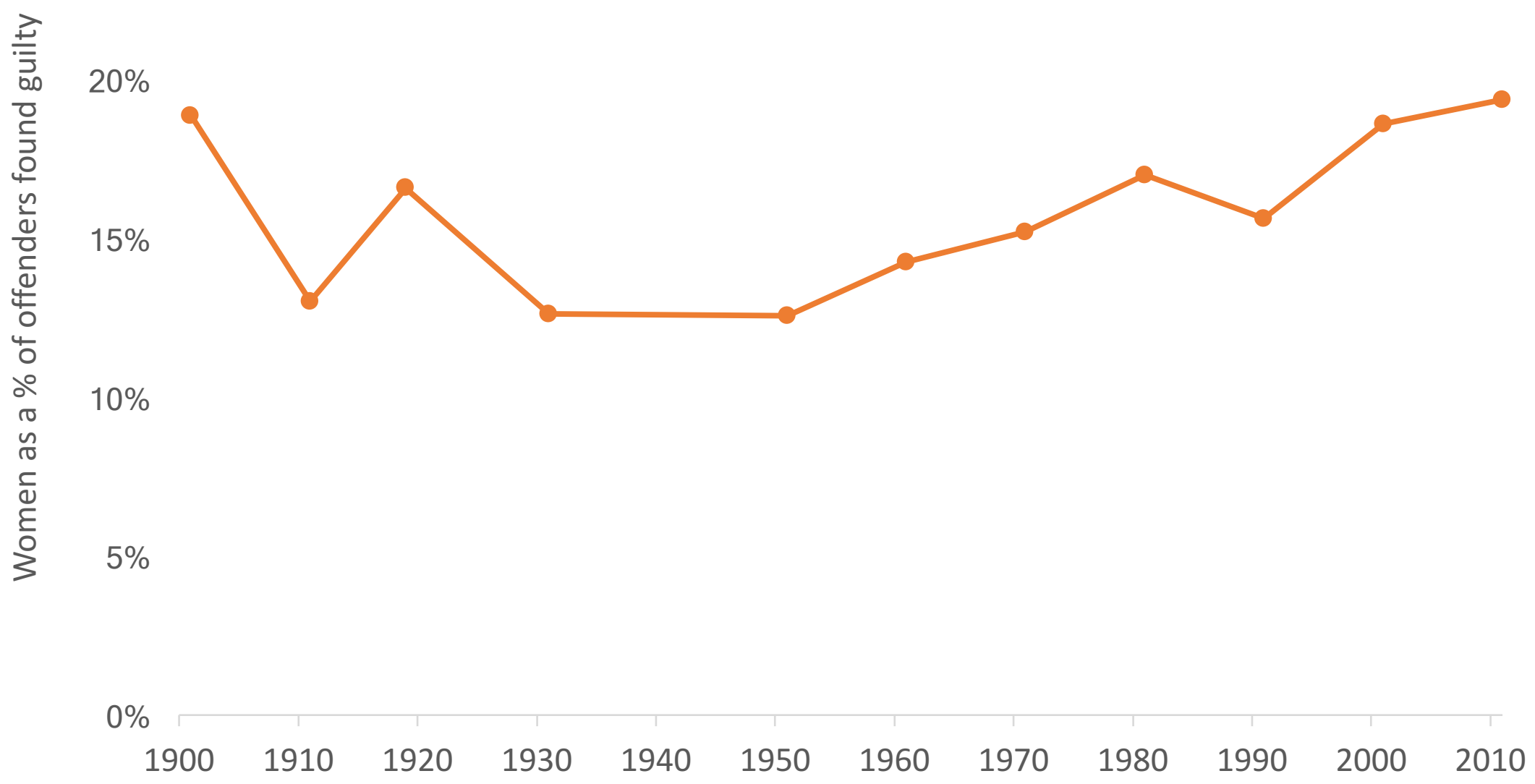

Source: Author's calculations; Home Office Criminal Statistics, England and Wales (various years); Ministry of Justice, Criminal Justice System statistics quarterly, England and Wales. 
Figure 2.3. Women as a \% of offenders found guilty for indictable offences in England and Wales, 1901 - 2011

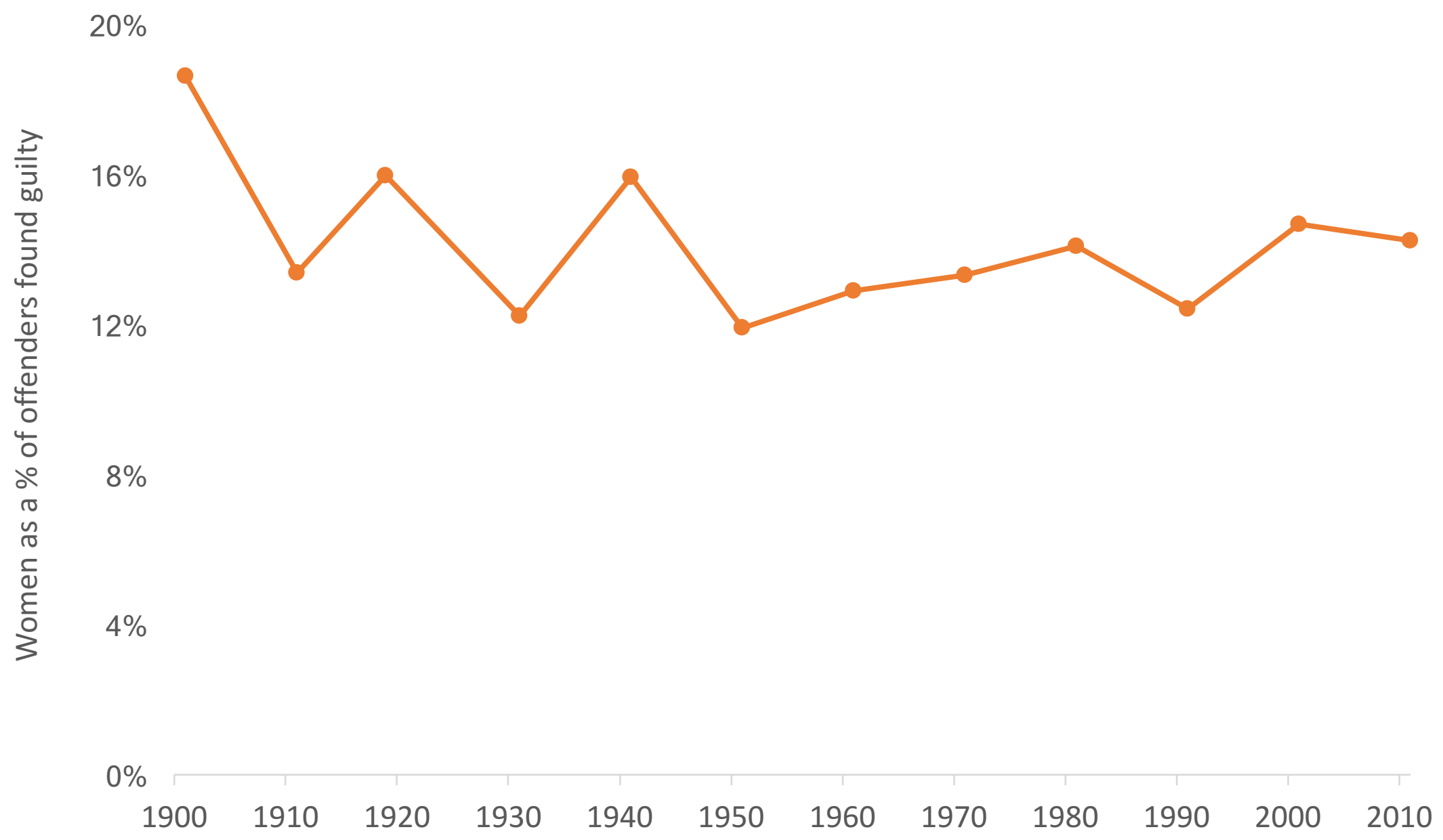

Source: Author's calculations; Home Office Criminal Statistics, England and Wales (various years); Ministry of Justice, Criminal Justice System statistics quarterly, England and Wales. 
Figure 3. Female labour force participation (as a percentage of the female working age population) in Great Britain, 1841 - 2001

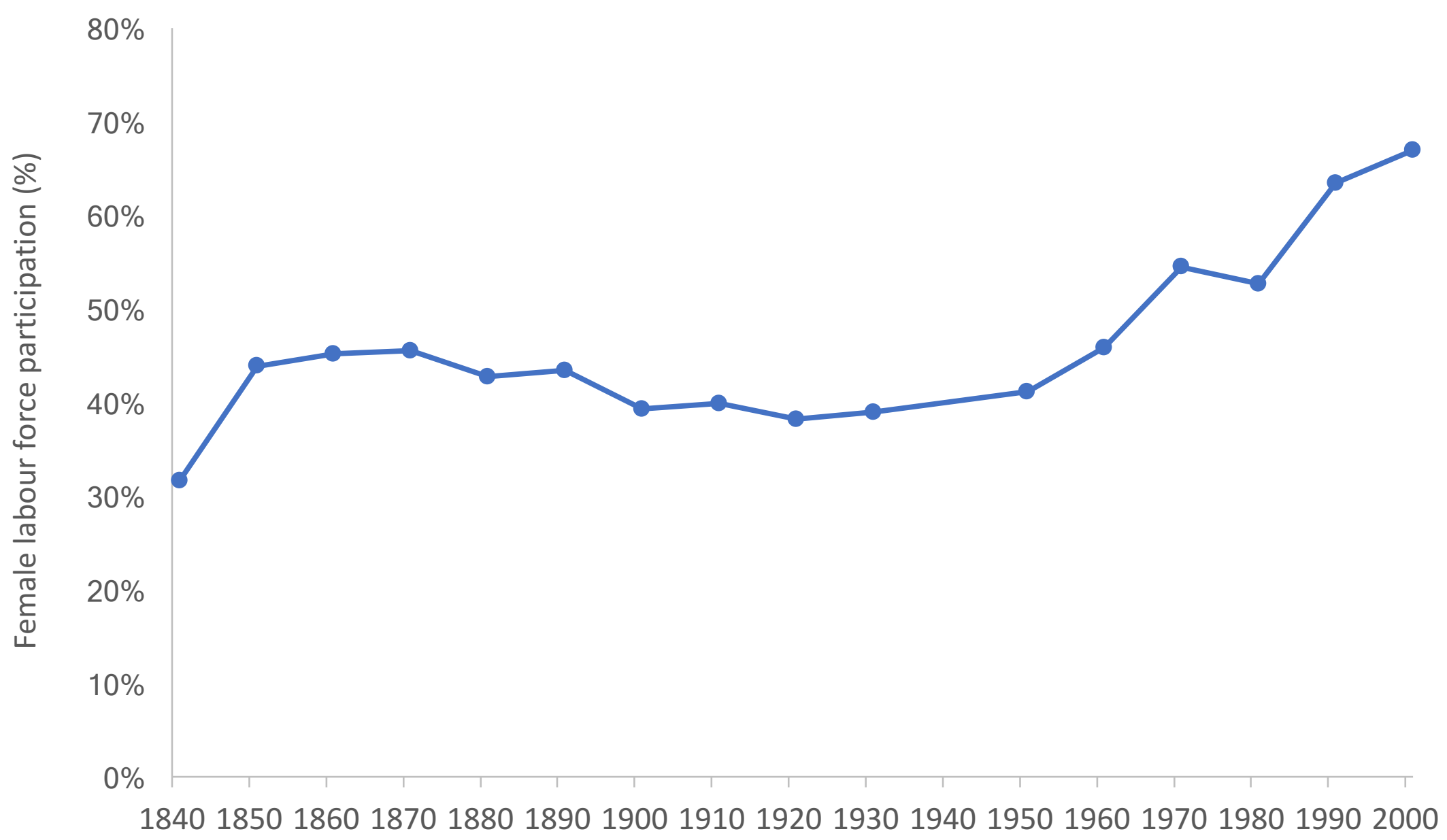

Source: Author's calculations; Palgrave Macmillan Ltd (Ed.). 2013. International Historical Statistics 17502010: Europe. Palgrave Macmillan UK. 
Students obtaining university degrees, UK

\begin{tabular}{rrrrrrrrr}
\hline & \multicolumn{3}{c}{ First degrees } & & \multicolumn{3}{c}{ Higher degrees } \\
\cline { 2 - 5 } \cline { 6 - 8 } \cline { 6 - 8 } & Men & Women & Total & & Men & Women & Total \\
\hline 1920 & 3,145 & 1,212 & 4,357 & & 529 & 174 & 703 \\
1930 & 6,494 & 2,635 & 9,129 & & 1,123 & 200 & 1,323 \\
1938 & 7,071 & 2,240 & 9,311 & & 1,316 & 164 & 1,480 \\
1950 & 13,398 & 3,939 & 17,337 & & 2,149 & 261 & 2,410 \\
1960 & 16,851 & 5,575 & 22,426 & & 2,994 & 279 & 3,273 \\
1970 & 35,571 & 15,618 & 51,189 & & 11,186 & 1,715 & 12,901 \\
\hline 1980 & 42,831 & 25,319 & 68,150 & & 14,414 & 4,511 & 18,925 \\
1990 & 43,297 & 33,866 & 77,163 & & 20,905 & 10,419 & 31,324 \\
\hline 2000 & 109,930 & 133,316 & 243,246 & & 46,015 & 40,520 & 86,535 \\
2005 & 122,155 & 156,225 & 278,380 & & 63,035 & 62,050 & 125,085 \\
2010 & 144,980 & 185,740 & 330,720 & & 93,375 & 89,235 & 182,610 \\
2011 & 153,235 & 197,565 & 350,800 & 96,280 & 97,990 & 194,270 \\
\hline
\end{tabular}

Notes:

All figures are for students from all domiciles

Full-time first degree students only 


\section{Timeline}

- 1870 Married Women's Property Act (extension of property rights)

- 1918 Representation of the People Act (partial franchise)

- 1919 Sex Disqualification (Removal) Act (formal access to professions and Civil Service)

- 1925 Law of Property Act (equal Inheritance rights)

- 1928 Representation of the People (Equal Franchise) Act (universal suffrage)

- 1964 Married Women's Property Act (extended rights to marital property)

- 1967 Abortion Act; contraceptive pill becomes available in NHS clinics

- 1970 Equal Pay Act (equal pay for like work)

- 1973 Matrimonial Causes Act; Guardianship Act (grounds for divorce law; equal custody rights on divorce)

- 1975 Sex Discrimination Act

- 1976 Domestic Violence and Matrimonial Proceedings Act

- 1985 Equal Pay (Amendment) Act (equal pay for work of equal value)

- 1986 Statutory Maternity Pay (General) Regulations (statutory maternity pay)

- $1991 R v R$ House of Lords abolishes marital rape exemption 